\title{
Peeling the onion: an approach to comparing vessel glass assemblages
}

\author{
H. E. M. Cool and M. J. Baxter
}

Roman sites frequently produce large quantities of artefacts which are identified, catalogued and published with no little expenditure of time and effort. This material should be one of the most important resources for telling us about the lives of the people who used it, but to a large extent its potential is untapped. The comparison of assemblages of finds from sites of different types and dates to see if recurrent patterns emerge promises to be one way of exploiting the resource, and this paper explores a methodology for doing this. It is rooted in a particular category of find and area (vessel glass and the province of Britannia), but we believe the approach could have wider applications. In it we seek to reveal the different types of information that the data may possess. All assemblages are likely to be the product of many different influences. Chronology, geography, status, gender, and the ways in which the material enters the archaeological record are ones that immediately spring to mind, and many others could be suggested. Some may be so dominant that the patterns they produce may mask those due to other influences. Our aim is to identify the major influences, and then progressively to analyse the data so that the effect of the dominant factors is removed, and the patterns produced by the less dominant ones are revealed. The gradual peeling of the layers of an onion to reveal a smaller, and sometimes differently-shaped or double core, may be a good analogy for the method.*

\section{Vessel glass and Roman Britain}

The Roman world saw a great explosion of the use of glass vessels during the later 1st c. B.C. and the early 1st c. A.D. Not only was the scale of production of cast vessels greatly increased, but the discovery of blowing allowed the rapid production of a whole range of new forms, including the closed ones that had hitherto been difficult to produce. This meant that glass vessels could be used as both tablewares and more mundane containers. With the advent of blowing, the price fell, so that by the Neronian period writers marvelled at how cheap glass cups were. ${ }^{1}$

Despite this expansion of use in the Roman world, glass vessels were virtually unknown in Britain prior to the Claudian invasion of 43 . Though Strabo ${ }^{2}$ numbered glass vessels amongst the items imported into Britain during the Augustan period, a recent survey of the fragments from pre-conquest contexts could point to only 7 sites, concentrated in the south-east, where such material was present. ${ }^{3}$ Even at those sites glass vessels must have been an exotic novelty as, in the majority of cases, the fragments can only have related to, at most, two vessels. This is in contrast to the situation with other pre-conquest imports from the Roman continent. In the same SE and south-central area, for example, imported pottery appears to account for sizeable proportions of pottery assemblages. ${ }^{4}$ These contrasting patterns strongly suggest that the rarity of

* All dates are A.D. unless otherwise stated. The following abbreviations are used:

AnnAIHV Annales du ... Congrès de l'Association Internationale pour l'Histoire du Verre (Amsterdam);

Colchester H. Cool and J. Price, Roman vessel glass from excavations in Colchester, 1971-85 (Colchester Archaeological Report 8, 1995);

Isings C. Isings, Roman glass from dated finds (Groningen-Djakarta 1957);

RepSocAnt Reports of the Research Committee of the Society of Antiquaries of London.

1 For an overview of the development of the early Roman glass industry, see D. Grose, Early ancient glass (New York 1989) 241-43. For comments on the cheapness of glass, Petr., Sat. 50.

2 Strab. 4.5.3.

3 J. Price, "A ribbed bowl from a late Iron Age burial at Hertford Heath, Hertfordshire," AnnAIHV 13 (1996) 47-54, esp. 52-53 and figs. 5-6.

4 S. Willis, "The romanization of pottery assemblages in the east and north-east of England during the 
pre-conquest glass vessels was a real one, and is not the result of insufficient excavations at the relevant sites. Immediately after the conquest, vessel glass fragments begin to be found in some quantity on a large range of sites, and it is clear that glass vessels poured into the province.

The association between the incorporation of Britain into the Roman empire and the use of glass vessels in the new province provides an opportunity to explore how the inhabitants adapted to the new circumstances. The vessels were not adopted uniformly by all sectors of the community; some communities apparently favoured certain types in preference to others. We know from the ancient writers that glass vessels were used for a wide range of purposes. Ignoring the more specialised uses, the commonest functions appear to be as drinking vessels, as vessels for presenting food and wine at table, as containers for storing and preserving food and drink, and as containers for storing perfumes and medicines. ${ }^{5}$ The wide range of vessel shapes found supports this range of functions. ${ }^{6}$ Occasionally the recurring association of a particular form with a specialised type of building will suggest the function of the vessel, the classic example being the two-handled spherical flasks frequently found in bath-houses that clearly functioned as oil containers, ${ }^{7}$ but such associations are rare. Although in most cases it is not possible to say with certainty what many forms were used for, it does seem reasonable to make certain assumptions about the relationship between form and function. Admittedly, different cultures can evolve very specialised vessel forms especially where drinking is concerned, but these are often associated with particular circumstances. The English yard-of-ale and the Spanish porron are good examples: both are tavern glasses but even within bars they form a small proportion of the drinking vessels, most people using more straightforwardly practical vessels. In a Roman context it seems reasonable to assume that the large numbers of cup and beaker forms were probably used as drinking vessels, just as the common blue/green bottle was used as a utilitarian container. Using such assumptions, this paper will concentrate on a functional approach to the study of glass assemblages to see if different sections of the population were using glass vessels for different purposes. It will concern itself with the type of glass used on settlement sites and ignore those placed in graves. The aim of the paper is to explore the functional patterns in broad outline to provide a background against which more detailed studies can take place. Insights may also be gained, however, by pursuing a more narrowly typological approach, and an example of this will be provided at the end to demonstrate the potential of more tightly focussed analyses.

In the next section the methodology adopted is described in detail and the assemblages used are introduced. The following section explores the patterns in the data. The final section attempts to set these patterns within the broader context of Romano-British studies.

\section{Comparing assemblages}

The systematic comparison of archaeological assemblages promises to be a powerful tool in understanding the past. It is based on the premise that regularly occurring patterns of associations are likely to reflect patterns of activity and behaviour in the past. In order to ensure this, however, there are a variety of issues that have be considered, so that any bias stemming from archaeological methodology can be eliminated. Questions that need to be asked include those about the comparability of sites and the nature of the material to be compared, and the quantification of the material. In some cases a technical solution is possible; in others, more pragmatic ones have to be accepted. The way that we have approached the questions is outlined

first century A.D.," Britannia 29 (1996) 179-221, esp. 191.

5 M. Trowbridge, Philological studies in ancient glass (Univ. of Illinois Studies in Language and Literature 13, 1930) 155-78.

6 For an overview of the typical vessel forms in use in Roman Britain from the mid 1st to early 5 th c., see Colchester figs. 13.1-13.7.

7 Isings Form 61; for examples of their associations with bath-houses, see Colchester 157. 
below, together with a discussion of the statistical methodology that is used to compare the quantified assemblages.

\section{Rubbish disposal and recycling}

How people dispose of rubbish can vary from community to community, household to household; when we compare assemblages this has to be kept in mind. It may be that any patterns that emerge are reflecting differential rubbish disposal rather than differential use. In this paper we favour the interpretation that the archaeological assemblage is reflecting, however indistinctly, use. It is open to others to re-interpret the patterns in the light of rubbish disposal habits.

A specialised form of rubbish disposal that affects broken glass is its collection and recycling for use as raw glass in the manufacture of fresh vessels. This practice is well-attested both in literary sources and in the type of debris that is found at glass-blowing sites. ${ }^{8}$ Recycling has the potential to alter the composition of archaeological assemblages, but to what extent it can seriously disrupt the patterns outlined below is open to question. In the methodology used here to compare assemblages, it is the proportion of each category in an assemblage that is of most importance, not the actual quantity; thus, the reduction in size of some assemblages due to more active recycling is not necessarily a problem. A problem could emerge, however, if some forms were being regularly selected for recycling in preference to others. From the glass-working point of view it is likely that larger, more substantial, vessels such as bottles would be favoured, in preference to thin-walled drinking vessels, as the former would provide more raw material. In other categories of material it would appear that a similar practical approach to recycling was adopted..$^{9}$ If this is indeed the case for the glass industry, then any bias should operate uniformly across the assemblages from different sites.

\section{The sites, the assemblages and their comparability}

The sites from which the principal assemblages are drawn were selected on the grounds that the complete glass assemblage recovered during excavation had been kept and studied, and that the full contextual record of the site was available. This was to ensure that the groups of glass were complete and could be independently dated by their stratigraphy. This condition had the effect of limiting the sites to those that had been excavated and studied relatively recently, as early publications of glass assemblages were often selective and frequently concentrated on the more 'interesting' pieces. Because the sites had all been professionally excavated in the past few decades, it was further hoped that no bias had crept into the sample due to differing excavation methodologies. A very small number of additional assemblages, where it is unclear whether they were complete groups, were derived from published sources. These were well-stratified and closely-dated assemblages where it appeared likely that they were complete. If there is any ambiguity about the quality of the assemblage, this is noted in the list of sites (Appendix 1).

The assemblages of the 1st-3rd c. were all selected on basis of their stratigraphic position using dating information derived from other classes of finds. Groups that clearly contained a high proportion of residual material were excluded. It was found that in general this solution was not suitable for the 4th-c. material as the bulk of this was often not found stratified in contemporary contexts. On sites that eventually became mediaeval towns, the robbing of the Roman structures often led to a disturbance of the later Roman layers, with consequent displacement of the material found within them to positions later in the stratigraphic sequence. A similar problem was also noted on rural sites where agricultural activity often resulted in 4th-c. material being found in the ploughsoil. The 4th-c. assemblages were therefore derived on typological grounds. Fortunately, towards the end of the $3 \mathrm{rd}$ c. a very noticeable change in the type of glass being used to make vessels can be observed. Prior to this, most vessels were made either in good quality colourless glass or in blue/green glass. Most 4th-c. vessels, by contrast, are made in a very distinctive bubbly glass in a range of shades of green and greenish colourless. ${ }^{10}$ The 4 th-c. assemblages from the sites therefore consist of all of the

9 W. Manning, "The iron objects," in L. Pitts and J. K. St. Joseph, Inchtuthil: the Roman legionary fortress (Britannia Monograph 6, 1985) 291. 


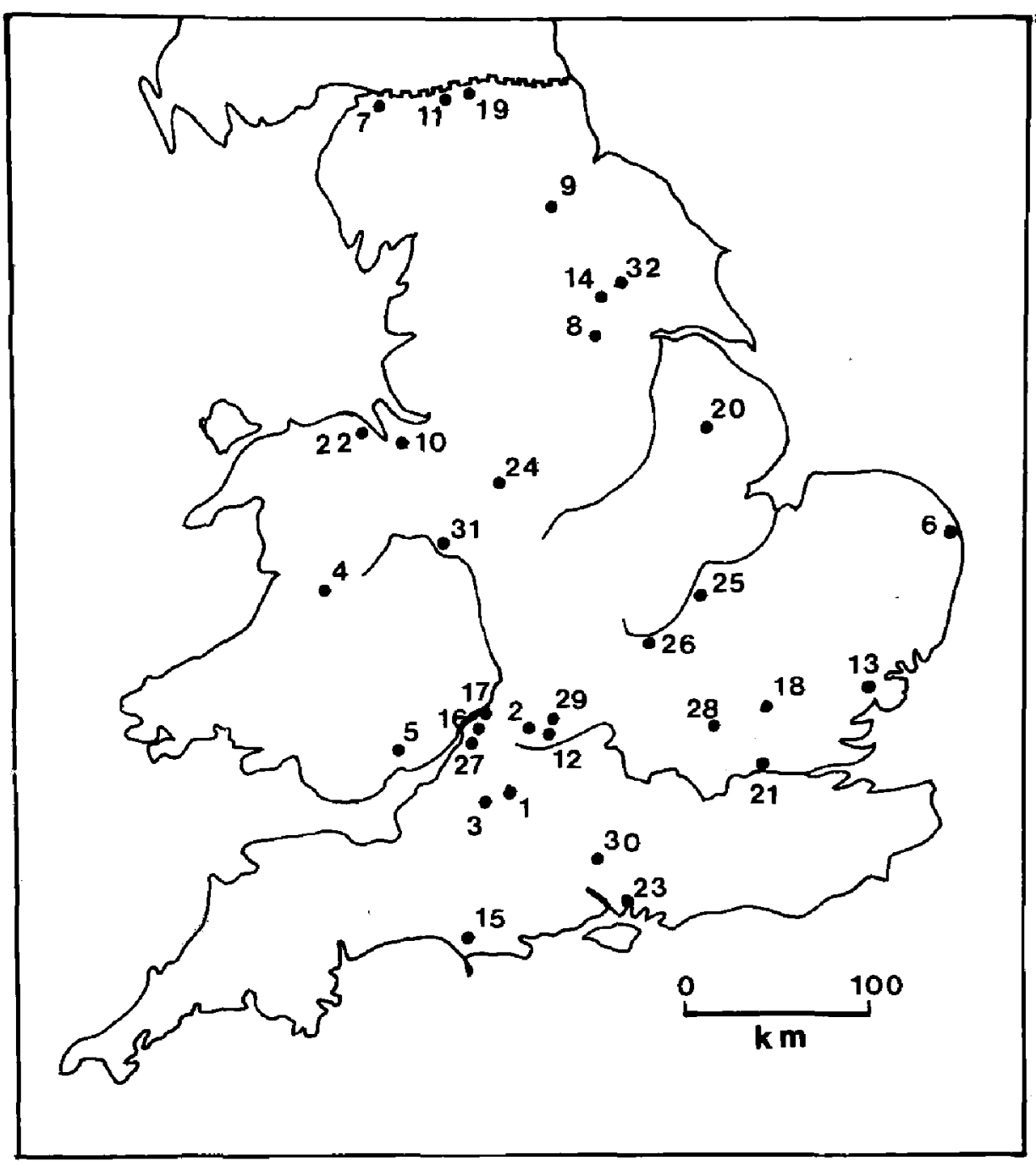

Fig. 1. Location of sites contributing assemblages discussed here.

1 Atworth; 2 Barnsley Park; 3 Bath; 4 Caersws; 5 Caerleon; 6 Caister; 7 Carlisle; 8 Castleford; 9 Catterick; 10 Chester; 11 Chesterholm; 12 Claydon Pike; 13 Colchester. 14 Dalton Parlours; 15 Dorchester; 16 Frocester Court; 17 Gloucester; 18 Harlow; 19 Housesteads; 20 Lincoln; 21 London; 22 Pentre Farm; 23 Portchester; 24 Rocester; 25 Stanwick; 26 Towcester; 27 Uley; 28 Verulamium; 29 Wilcote; 30 Winchester; 31 Wroxeter; 32 York.

fragments in this distinctive bubbly glass irrespective of stratigraphic position.

In total, 60 separate excavations have contributed data for this study. Brief details of them are given in Appendix I and their locations are shown here in fig. 1.

Quantifying the data

Vessel glass from domestic sites of the type to be compared is almost invariably found as small broken fragments. This causes problems when attempting to quantify it in a consistent way that is neither influenced by the depositional history of the site, nor by the area of the site excavated. These are exactly the same problems that beset the quantification of pottery assemblages. There is a considerable literature exploring the best ways to quantify pottery ${ }^{11}$ and this work has shown that fragment counts are clearly influenced by the depositional history of a site, with a more disturbed area likely to produce greater fragmentation postdepositionally than a non-disturbed one. Measures based on maximum or minimum numbers will depend very

11 This has been summarised in C. Orton, "How many pots make five? An historical review of pottery quantification," Archaeometry 35.2 (1993) 169-84. 
much on the size of the assemblage. For pottery, the most stable measures appear to be either weight or the Estimated Vessel Equivalent (EVE), with the latter being preferred.

In pottery vessel assemblages, rim EVEs, which measure the proportion of the rim extant, are frequently used. For glass vessels, much valuable information about the composition of the assemblage resides in handle and body fragments. Given that glass assemblages are always much smaller than pottery ones because of the re-cycling of broken glass, ${ }^{12}$ there is a need to maximise the information from all elements. Clearly rim EVEs are inappropriate for glass vessels, so a method of calculating EVEs based on the proportion of the profile of the form that the fragment represents has been devised. ${ }^{13}$ All of the assemblages in this study have been quantified by this method.

\section{Form and furtction}

Individual types can have relatively short life-spans. This is particularly true of tablewares, which tend to come and go at the whim of fashion, but even the most long-lived utilitarian container form does not remain unchanged over the centuries. A survey such as this which aims to trace changes over nearly four centuries needs to simplify individual types into more generic forms. The definition of the forms used in this study are given below. Fig. 2 shows individual types typical of each form.

Drinking vessels are open vessels with simple rims that are normally cracked-off or fire-rounded. ${ }^{14}$ The rim is either vertical or slightly in- or out-bent. Their diameter rarely exceeds $100 \mathrm{~mm}$ and they could easily have been held in one hand.

Bowis are open vessels that, based on either their size, rim thickness or rim form, would seem to have been unsuitable for drinking from. Some were clearly intended as platters or dishes, and many others would have been best suited for serving food. It is open to question whether the very common pillar moulded bowl of the 1st $c .{ }^{15}$ was regularly used as a drinking vessel. Some probably were, but others, such as the wide shallow forms, would have been most impractical for the purpose, though this, of course, does not rule out the possibility. A similar ambiguity besets some 4 th-c. forms such as the segmental bowl. ${ }^{16}$ Some do have drinking mottoes incorporated into their decoration, ${ }^{17}$ designed to be viewed through the vessel. It should be noted, however, that the position of the inscription around the rim would have rendered it invisible to any drinker. The drinker would be more likely to appreciate the motto if placed centrally on the base. If these large hemispherical or segmental bowls were used as drinking vessels, they would have had to have been held in both hands and drunk from with care, by comparison to the cups and beakers which could easily be used one-handed.

Jars are closed vessels with short necks and relatively wide rim apertures. They would have been ideal for storing solid contents.

Flasks are closed forms with long necks and no handles that can only have contained liquids. The specialised form of the bath flask with its short neck and two handles has been included here as there are grounds for thinking that, before it became popular in the later 1st c., long-necked vessels of the type defined here as flasks served a similar purpose. ${ }^{18}$

Jugs are closed forms with handles. The necks may be long and they may have pouring spouts. The bodies generally have conical, globular or ovoid outlines. They too can only have contained liquids.

Bottles are closed forms with short necks and handles. The bodies are designed to maximise their capacity in relationship to their height so the body is frequently cylindrical or prismatic. The narrowness of the necks on many means that they can only have held a liquid, but some large bottles of the 1 st and 2 nd c. ${ }^{19}$ do have necks that are wide enough for a solid content.

12 Colchester 6-7.

13 H. Cool and M. Baxter, "Quantifying glass assemblages," AnnAIHV 13 (1996) 93-101.

14 Definitions of technical manufacturing terms will be found in Colchester 8.

15 Isings Form 3.

16 Isings Form 116.

17 D. Harden, "The Wint Hill hunting bowl and related glasses," JGS 2 (1960) 51.

18 J. Price, "Glass vessels," in W. Manning, J. Price and J. Webster, Report on the excavations at Usk 1965 1976: the Roman small finds (Cardiff 1995) 172. See also the regular occurrence of long-necked flask fragments in 1st-early 2nd c. bath-house drain deposits such as at Caerleon: D. Allen, "The glass vessels," in D. Zienkiewicz, The legionary fortress baths at Caerleon. II. The finds (Cardiff 1986) 99-103, nos. 2, 8-10, 20. 


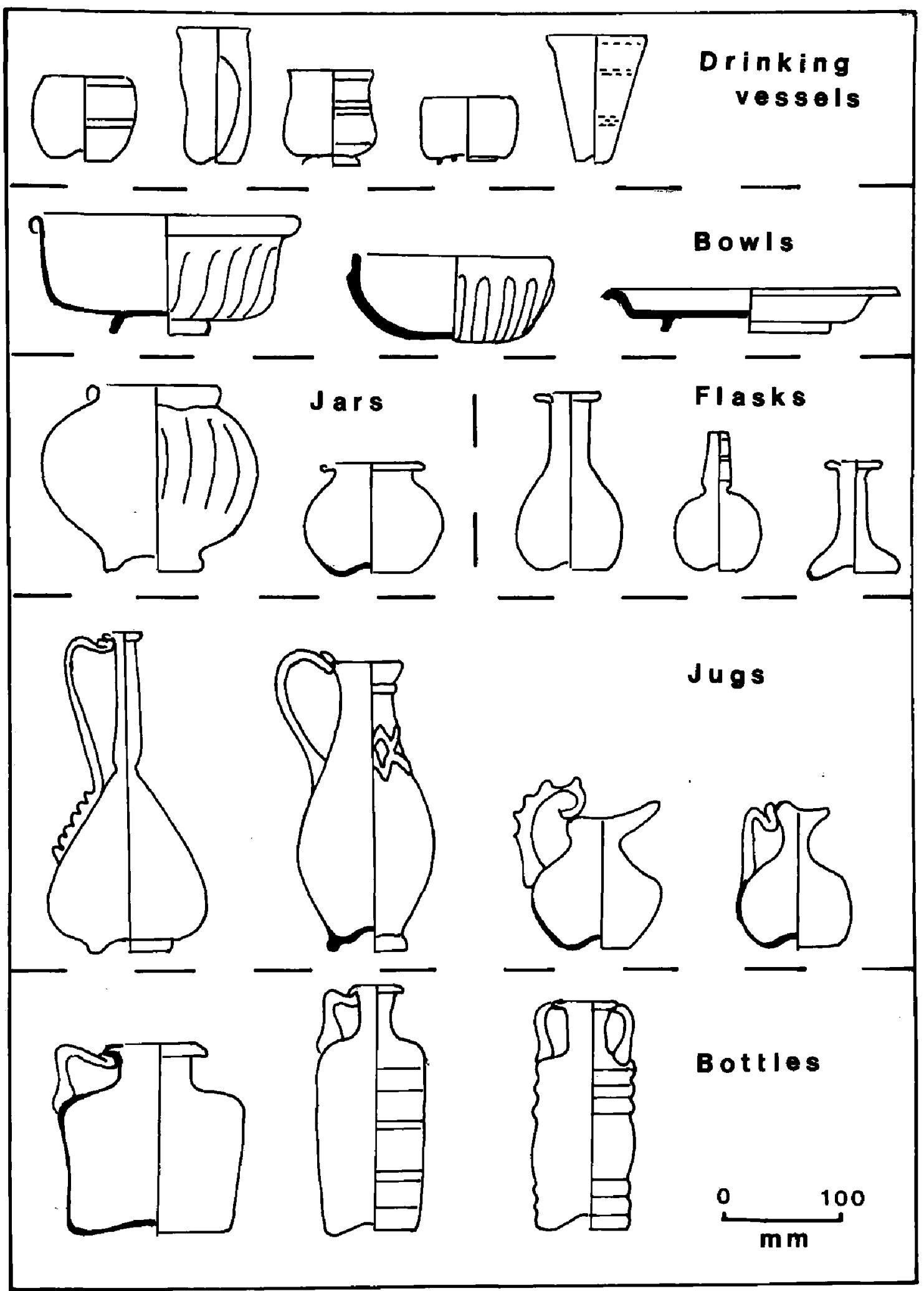

Fig. 2. Examples of typical vessel forms. 


\section{Correspondence Analysis (CA)}

Once the assemblages have been quantified, it is possible to summarise the amount of particular functional forms or individual types at any one site. For comparative purposes these summaries can be expressed as tables where the rows are individual sites and the columns are the forms or types. These are tables of counted data, and a statistical technique for analysing such a table is Correspondence Analysis. ${ }^{20} \mathrm{It}$ is a descriptive technique which displays pattern in the data. As we shall use CA plots extensively in this paper to illustrate the patterns, it is appropriate to outline here in simple terms what the techrique is doing and how the plots should be read. A full treatment of the technique will be found in the references cited. A note on statistical software to implement CA, and a consideration of how it has been used in Roman archaeology, is given in Appendix 2.

The output is presented as two plots, the row plot (which will always be on the left in the figures) and the column plot. The technique works by converting the values in each row to percentages of the total value for that row. Here the rows are sites and the columns are forms or types, so the effect is that each site is described by the proportion of each form present. On the row plot, sites which have relatively similar proportions of each form will be shown in the same area of the plot. The columns are processed in a similar way to the rows and a column plot produced. In the analyses here this has the effect of describing each form by the proportion of it found on different sites, and on the column plot the forms that have a similar site profile are shown in the same area of the plot. The plots should be read in relation to the origin (the point where the axes cross). A group of sites in one area of the site or row plot will generally have a more than usually high proportion of the forms which are plotted in the same position, relative to the origin, on the form or column plot.

In addition to the pictorial output, $C A$ also produces statistics that indicate how well the plots are representing the data. Inertia is the term used for describing how much variation in the data is explained by each axis, and on each plot this value will be noted in the caption. A plot is a good representation of the data if the combined inertias for the 1st and 2nd axes form a high percentage of the total inertia. It is also possible to decompose the inertia to examine how well individual sites or forms are represented on a plot, and this will be done as appropriate.

The way in which CA processes the data, by comparing the proportions of forms in assemblages, is especially suitable for this study since the assemblages often differ greatly in size. Cortespondence analysis weights the assemblages according to their absolute size, so that large assemblages have more influence than small ones. An attempt has been made to avoid very small assemblages wherever possible but for some of the more detailed comparisons they had to be used. Reference will be made to the diagnostic statistics in these cases as they can provide information on the quality of the representation on the plot of these small groups.

From an archaeological point of view a comparison of the absolute volume of glass vessels being disposed of on a site would also be of interest. At present this may be done subjectively. For example, the volume from urban sites generally appears to be greater than that from rural ones, but it cannot be done quantitatively. This would require the ability to standardise the size of the assemblage using information about the volume of the site that had been dug, information that in our experience is never available.

\section{Patterns in the glass}

It is clear that a variety of factors influence the types of assemblages that have been recovered, and the analyses reported on below have been designed to show them. The approach adopted is one that moves from the general to the more particular, sequentially focussing the analyses more narrowly so that dominating influences, which may mask underlying patterns, can be discounted after their effect has been noted. This approach has been followed because earlier work based on minimum numbers suggested that time was a very important factor in the types of vessels found in Roman Britain with there being a progressive narrowing of the range of forms found. ${ }^{21}$

20 A full statistical treatment of this will be found in M. Greenacre, Correspondence Analysis in practice (London 1993). For a treatment designed for archaeologists see M. Baxter, Exploratory multivariate analysis in archaeology (Edinburgh 1994) 100-39, and S. Shennan, Quantifying archaeology (2nd ed., Edinburgh 1997) 308-41.

21 Colchester 223, 235-36. 


\section{An overview of the 1 st to 4 th $c$. assemblages}

The first analysis is designed to examine any broad patterns which can be accounted for by changes in time. Data has been gathered from 16 sites which provided large groups of material which either came from stratified contexts datable to the period between 70 and 150 or was typologically of 4th-c. date. 'Large' here was arbitrarily taken to be an assemblage with an EVE value of 10 or above, and the individual assemblages often came from more than one excavation in a town or fort. It was only possible to find two comparable assemblages from statigraphic contexts of the late 2 nd to mid $3 \mathrm{rd}$ c. which were large enough to be included in this analysis but which did not have a substantial residual component. These were included despite their slightly smaller size.

The range of sites includes military (both legionary and auxiliary) and urban (colonia, civitas capitals and small towns), but only one rural site (Stanwick) as no other rural assemblages could be found that fulfilled the size-requirement for this analysis. This was partially due to the fact that the quantity of vessel glass found on rural sites is generally smaller than that found in urban and military contexts, but also due to the fact that large rural assemblages which would probably have fulfilled the size requirement, such as those from Lullingstone, Kent $^{22}$ and Gorhambury, Herts., ${ }^{23}$ have not been studied in their entirety.

The data used for this analysis are summarised in Table 1, the second column indicating the date of the assemblage. Some differences are immediately apparent. Though jars are never a very large proportion of the earlier assemblages, they are conspicuous by their absence in the 4 th-c. ones. It is also clear that drinking vessels form a much larger proportion of 4 th-c. assemblages than they did earlier, and bottles a smaller one.
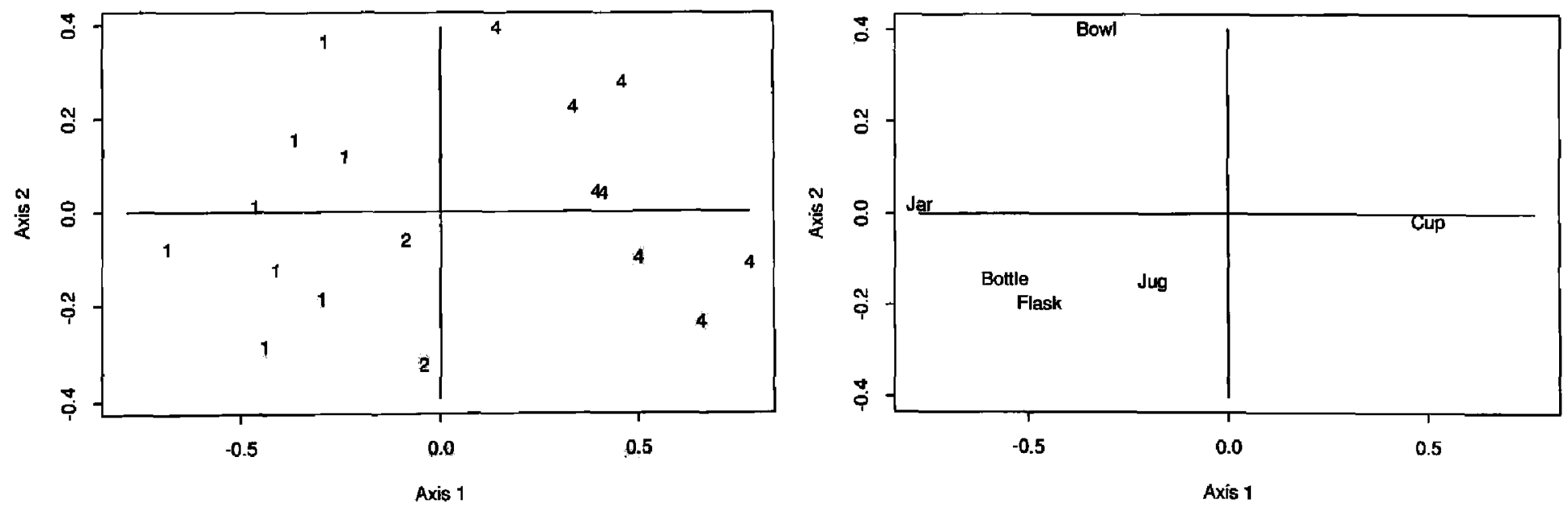

Fig. 3. Correspondence Analysis plot of 1st-4th c. assemblages (74\% of the inertia accounted for by the first axis, $11 \%$ by the second).

Figure 3 shows the CA plot of this table with the sites labelled by the date of the assemblage. ${ }^{24}$ Given the differences already noted in the Table, it is not surprising that the plot

22 H. Cool and J. Price, "The glass," in G. Meates, The Roman villa at Lullingstone, Kent. II. The wall paintings and finds (Kent Arch. Soc. Monograph 3, 1987) 110-42, esp. 110.

23 D. Neal, A. Wardle and J. Hunn, Excavation of the Iron Age, Roman and Medieval settlement at Gorhambury, St. Albans (English Heritage Arch. Rep. 14, 1990) 201-5.

24 In this and the following CA plots where the sites have been labelled generically by date or type, the position of the individual sites on the plot will be given as a footnote. The sites will be listed in the 
shows a clear distinction between the assemblages belonging to the 1st-3rd c. and those of the 4 th, with the latter being characterised by high proportions of drinking vessels. There are also indications that the $2 n d-3 r d ~ c$. assemblages may be differentiated from those of the 1st-2nd c. Clearly time is an important influence on the forms of vessels being used, and any exploration of the patterns of use in different types of sites or in different regions will have to eliminate this strong chronological structure. This can best be achieved by looking first at the assemblages of the 1st-3rd c. and then separately at those of the 4th c.

\begin{tabular}{lcccccccc}
\multicolumn{10}{c}{ TABLE 1: COMPARISON OF 1st TO 4th c. ASSEMBLAGES } \\
Site & Date & Cup & Bowl & Jar & Flask & Jug & Bottle & Total EVE \\
Carlisle & 1st/2nd & 4.40 & 6.80 & 1.10 & 2.44 & 4.22 & 14.44 & 33.40 \\
Colchester & 1st/2nd & 9.20 & 5.60 & 1.80 & 1.49 & 3.00 & 5.75 & 26.84 \\
Castleford & 1st/2nd & 6.40 & 4.20 & 0.52 & 3.68 & 2.72 & 7.28 & 24.80 \\
Chester & 1st/2nd & 4.00 & 3.52 & 0.69 & 0.94 & 1.54 & 3.78 & 14.47 \\
Dorchester & 1st/2nd & 3.60 & 1.20 & 1.43 & 2.94 & 1.42 & 2.52 & 13.11 \\
Gloucester & 1st/2nd & 5.60 & 5.20 & 1.03 & 3.02 & 2.84 & 6.72 & 24.41 \\
Wroxeter & 1st/2nd & 5.20 & 2.13 & 0.57 & 1.84 & 2.40 & 4.48 & 16.62 \\
York & 1st/2nd & 6.40 & 6.00 & 1.44 & 2.20 & 0.84 & 3.08 & 19.96 \\
Lincoln & 2nd/3rd & 4.20 & 0.40 & 0.40 & 0.65 & 1.37 & 2.31 & 9.33 \\
York & 2nd/3rd & 4.20 & 1.40 & 0.36 & 0.60 & 1.12 & 2.31 & 9.99 \\
Caister & 4th & 25.80 & 0.80 & 0 & 0.80 & 0.70 & 1.84 & 29.94 \\
Colchester & 4th & 9.20 & 3.20 & 0 & 1.02 & 1.44 & 0.61 & 15.47 \\
Dorchester & 4th & 5.00 & 2.80 & 0 & 0 & 0.84 & 1.36 & 10.00 \\
Stanwick & 4th & 8.73 & 1.80 & 0 & 0.27 & 1.47 & 1.45 & 13.72 \\
Towcester & 4th & 9.40 & 0 & 0 & 0.07 & 1.18 & 1.27 & 11.92 \\
Winchester & 4th & 10.20 & 2.00 & 0 & 0.60 & 1.26 & 1.56 & 15.62 \\
Wroxeter & 4th & 24.20 & 2.60 & 0 & 1.80 & 4.13 & 2.32 & 35.05 \\
York & 4th & 10.00 & 3.00 & 0 & 0.20 & 0.70 & 0.98 & 14.88
\end{tabular}

\section{1st -3rd c. assemblages}

Table 2 summarises 25 assemblages from stratigraphic contexts ranging from $c .70$ to $c .280$. In this analysis no attempt has been made to obtain groups of contemporary assemblages as was done in the previous analysis. Instead, the occupational history of the individual sites has been allowed to dictate the date ranges. This results in individual assemblages having a date range from as little as 10 years to as much as 120 but the average is just under 50 years. Again, those belonging to the 2 nd or $3 \mathrm{rd} \mathrm{c}$. have been selected because they are not noticeably contaminated with residual 1 st or early $2 \mathrm{nd} \mathrm{c}$. material and can therefore be assumed to be contemporary with the contexts in which they were found.

The assemblages fall into two broad categories. In some cases it has been possible to extract ones which are associated with particular buildings or activities. Examples of this include two assemblages associated with the use of the legionary bath-house at Caerleon (rows 6 and 24), a possible tribune's house at the same fortress (rows 4 and 17), two urban rubbish dumps from the large towns of London and Wroxeter (rows 1 and 22), two rubbish pits from smaller urban centres at Towcester and Harlow (rows 14 and 15), an assemblage derived from the accidental destruction by fire of an urban insula at Verulamium (row 13), and an assemblage from the praetorium of the auxiliary fort at Housesteads (row 20). The second category consists of assemblages which are less narrowly focussed but all can be related to particular episodes, such as the occupations of particular military sites (see rows $2,3,5,7,8,18$, and 25), larger urban centres

order they appear, from left to right, on the first axis. For fig. 3 the order is: Carlisle, Gloucester, Dorchester C1/2, Castleford, Chester, Wroxeter C1/2, York C1/2, Colchester C1/2, York C2/3, Lincoln, Dorchester C4, Colchester C4, Stanwick, Winchester, York C4, Wroxeter C4, Towcester, Caister. 
(rows 9-11, 21, 23), small towns or roadside settlements (rows 12 and 19), or official residences (row 16).
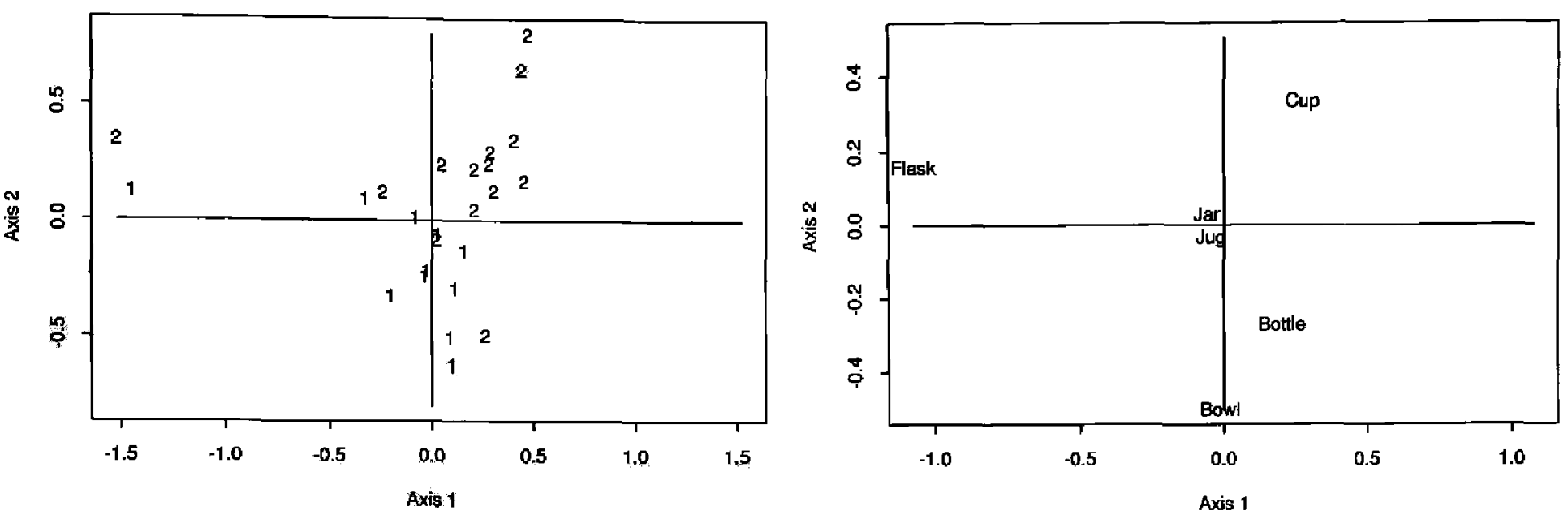

Fig. 4. Correspondence Analysis plot of 1 st-3rd c. assemblages ( $46 \%$ of the inertia accounted for by the first axis, $25 \%$ by the second).

The CA plot for this data is shown in fig. $4 .{ }^{25}$ The sites have again been labelled by the date of the assemblage, with those that fall within the 1st-mid 2nd c. being labelled 1 and those that are 2 nd or $3 \mathrm{rd}$ c. being labelled 2. Two assemblages on the left of the plot are clearly distinguished from the mass of the data by a much higher than normal proportion of flasks. Both of these assemblages come from the Caerleon bath-house and it is clear that in these cases the very specialised nature of a bath-house deposit is over-riding the chronological effect that is suggested by the rest of the plot. These two assemblages clearly dominate the plot: between them they account for $73 \%$ of the inertia on the first axis. If the same data set is re-analysed without the bath-house deposits, the resulting plot (fig. 5) ${ }^{26}$ clearly shows that chronology is still having a very strong effect on the types of assemblages recovered. Again, many of the later assemblages have a high proportion of drinking vessels, and on the column plot it is noticeable that bowls are diametrically opposed to drinking vessels. This implies that as the proportion of drinking vessels rises in an assemblage, the proportion of bowls falls, and vice versa. A shift towards the cup and beaker forms, here called drinking vessels, at the expense of bowls apparently starts to be noticeable in the 2 nd $\mathrm{c}$. The ambiguous function of bowls noted above allows a variety of interpretations of this pattern. If forms such as pillar moulded bowls were used primarily as drinking vessels, then the move to the cup/beaker forms could suggest a decrease in the volume being drunk at any one time or, if the bowls were communal vessels handed around, a move towards individual vessels. It should not be forgotten, however, that

25 The order of the sites (cf. n.24) is: Caerleon BH 160-230, Caerleon BH 80-110, Dorchester 70-150, Harlow 160-70, Castleford 70-95, London 70-95, Gloucester 70-98, York 70-120, Towcester 155-65, Wroxeter 80-150, Wroxeter 175-225, Caerleon TS 74-100, Carlisle 70-105, Chester 70-120, Colchester 65-150, York 175-250, Lincoln 160-230, Rocester 140-200, Pentre Farm 120-200, Castleford 140-180, Verulamium 150-60, Caerleon TS 130-200, York 160-280, Catterick 150-200, Housesteads 150-200.

26 The order of the sites (cf. n.24) is: Carlisle 70-105, Caerleon TS 74-100, Castleford 70-95, Rocester 140200, York 70-120, Gloucester 70-98, Chester 70-120, Towcester 155-65, Dorchester 70-150, Harlow 160-70, Colchester 65-150, London 75-90, Wroxeter 80-150, York 175-250, Wroxeter 175-225, Verulamium 150-60, Lincoln 160-230, Pentre Farm 120-200, Catterick 150-200, Castleford 140-80, Caerleon TS 130-200, York 160-280, Housesteads 150-200. 

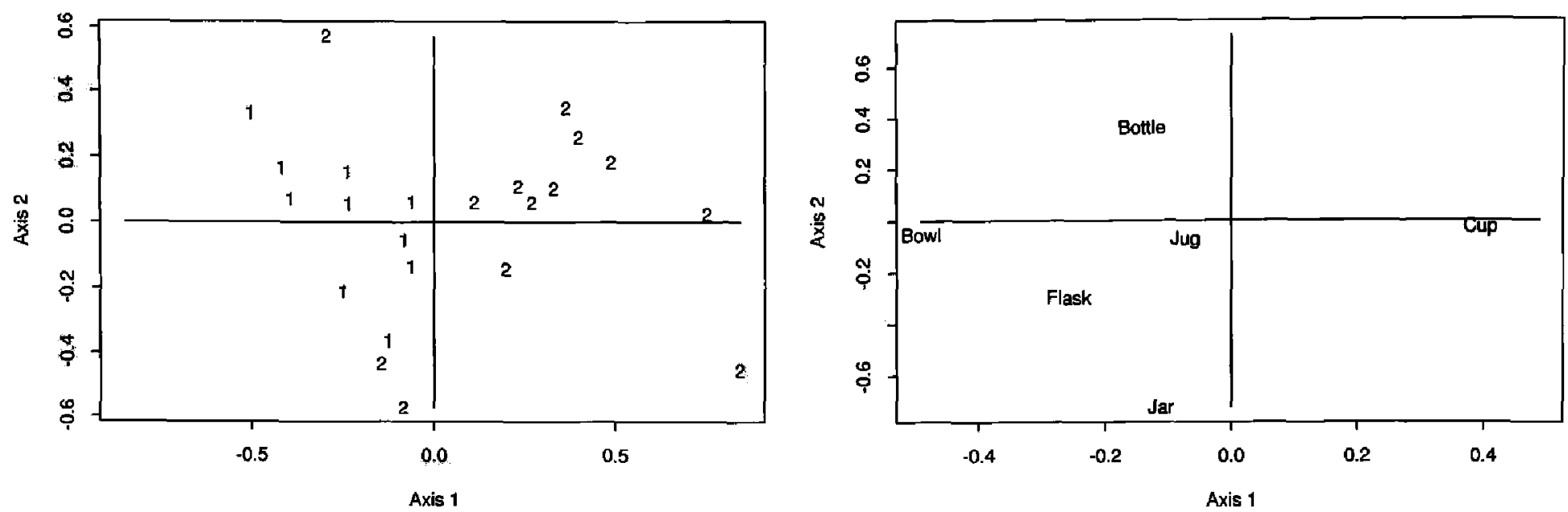

Fig. 5. Correspondence Analysis plot of 1st-3rd c. assemblages excluding the Caerleon bath-house assemblages ( $42 \%$ of the inertia accounted for by the first axis, $26 \%$ by the second).

many bowl forms would have been unsuitable as drinking vessels but ideal for the presentation of food. The increasingly high proportion of cup and beaker forms in assemblages from the 2nd $c$. indicates, at the very least, that glass vessels were increasingly used as individual drinking vessels, and that the other functions they might serve declined.

TABLE 2: COMPARISON OF 1st TO 3rd c. ASSEMBLAGES

$\begin{array}{lrlllllr}\text { Site } & \text { Cup } & \text { Bowl } & \text { Jar } & \text { Flask } & \text { Jug } & \text { Bottle } & \text { Total EVE } \\ \text { London 75 - 90 } & 7.60 & 4.20 & 0.20 & 2.88 & 3.64 & 2.52 & 21.04 \\ \text { Gloucester 71-100 } & 3.40 & 2.40 & 0.36 & 1.81 & 1.40 & 4.55 & 13.92 \\ \text { Castleford 70-100 } & 9.20 & 5.60 & 1.80 & 1.49 & 3.00 & 5.75 & 16.06 \\ \text { Caerleon TS 74-100 } & 1.80 & 2.60 & 0 & 0.50 & 0.42 & 1.82 & 7.14 \\ \text { Carlisle 71-105 } & 2.80 & 5.40 & 0.38 & 1.20 & 1.26 & 7.28 & 18.32 \\ \text { Caerleon BH 80-110 } & 0.60 & 0.80 & 0.28 & 3.73 & 0.14 & 0.56 & 6.11 \\ \text { Chester 75-120 } & 4.00 & 3.52 & 0.69 & 0.94 & 1.54 & 3.78 & 14.47 \\ \text { York 71-120 } & 6.40 & 6.00 & 1.44 & 2.20 & 0.84 & 3.08 & 19.96 \\ \text { Colchester 65-150 } & 9.20 & 5.60 & 1.80 & 1.49 & 3.00 & 5.75 & 26.84 \\ \text { Dorchester 70-150 } & 3.60 & 1.20 & 1.43 & 2.94 & 1.42 & 2.52 & 13.11 \\ \text { Wroxeter 80-150 } & 5.20 & 2.13 & 0.57 & 1.84 & 2.70 & 4.48 & 16.62 \\ \text { Castleford 140-80 } & 14.20 & 0.80 & 0 & 2.00 & 1.70 & 7.84 & 26.54 \\ \text { Verulamium 150-60 } & 5.00 & 1.20 & 0.34 & 0.40 & 1.10 & 2.53 & 10.57 \\ \text { Towcester 155-65 } & 2.40 & 1.60 & 1.31 & 0.60 & 1.40 & 1.14 & 8.45 \\ \text { Harlow 160-70 } & 5.60 & 2.40 & 2.80 & 3.20 & 0.98 & 2.12 & 17.10 \\ \text { PentreFarm 120-200 } & 5.80 & 1.40 & 0 & 0.67 & 0.49 & 1.96 & 10.32 \\ \text { Caerleon TS 130-200 } & 2.80 & 0.40 & 0 & 0.17 & 0.14 & 0.98 & 4.49 \\ \text { Rocester 140-200 } & 0.60 & 0.20 & 0.60 & 0.20 & 0.70 & 4.22 & 6.52 \\ \text { Housesteads 150-200 } & 5.40 & 0 & 1.00 & 0 & 0.56 & 0.14 & 7.10 \\ \text { Lincoln c.160-230 } & 4.20 & 0.40 & 0.40 & 0.65 & 1.37 & 2.31 & 9.33 \\ \text { Wroxeter c.175-225 } & 3.40 & 0.80 & 0.34 & 0.87 & 0.77 & 1.12 & 7.30 \\ \text { Catterick 150-250 } & 5.40 & 0.54 & 0.20 & 0.14 & 0.56 & 3.64 & 10.48 \\ \text { York c.175-250 } & 4.20 & 1.40 & 0.36 & 0.60 & 1.12 & 2.31 & 9.99 \\ \text { Caerleon BH 160-230 } & 1.80 & 0.60 & 0.17 & 8.29 & 1.59 & 0.56 & 13.01 \\ \text { York 160-280 } & 7.20 & 0 & 0.34 & 0.40 & 0.28 & 1.68 & 9.90\end{array}$


Three of the later assemblages occupy different parts of the plot than that occupied by the majority of the others of 2nd-3rd c. date. The assemblage towards the top of the plot is from the auxiliary fort at Rocester and is characterised by a high proportion of bottles. The two towards the bottom, characterised by a high proportion of jars, are the rubbish-pit assemblages from Harlow and Towcester. These three assemblages together with the bath-house assemblages from Caerleon show that, though the date of a site plays a very important rôle in determining what functional forms of glass vessels will be found on it, other factors may also be at work. The following two analyses explore what these factors might be by concentrating on more narrowly dated assemblages.

The first analysis uses the assemblages in Table 2 with date ranges in the later 1 st to mid 2nd c. excluding the bath-house deposits (i.e., rows 1-5 and 7-11). To these 10 sites have been added two contemporary assemblages from the vicus at Caersws and the small rural roadside settlement of Wilcote. ${ }^{27}$ The CA plot of this data is shown in fig. $6{ }^{28}$ where the sites are labelled according to whether they are military (M) or civilian (C) as this would appear to be an explanation for the differences between the proportions of forms found on the different sites. The military sites are characterised by a high proportion of bowls and bottles, whereas the civilian sites seem to have a more varied assemblage of forms possibly characterised by a slightly higher proportion of jugs and drinking vessels. The exception to this is the civilian site on the left of the plot characterised, like the military sites, by a high proportion of bowls and bottles: this is the small rural site of Wilcote. Despite the small size of the assemblage, an inspection of the diagnostic statistics shows that the quality of its representation on the plot is good. ${ }^{29}$
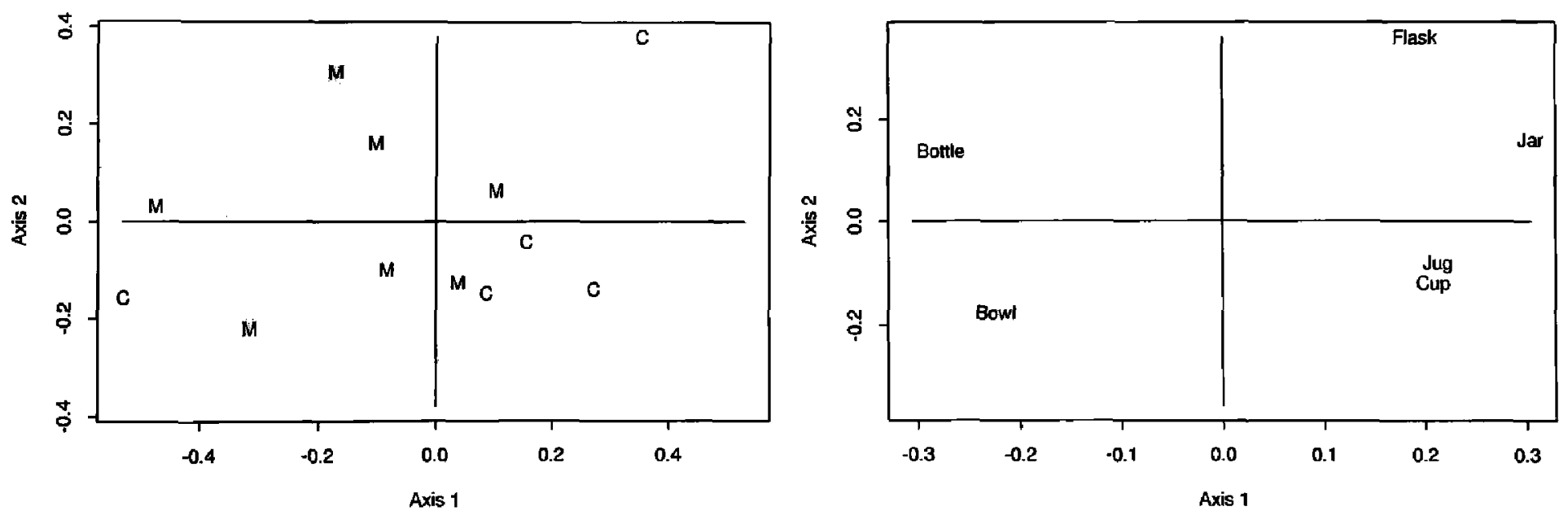

Fig. 6. Correspondence Analysis plot of 1 st-2nd c. assemblages ( $44 \%$ of the inertia accounted for by the first axis, $25 \%$ by the second).

The pattern seen in fig. 6 is an interesting one as it suggests that by the Flavian period the urban population in Britain had established its own way of using glass vessels that did not slavishly follow the military pattem. This military/urban contrast casts light upon how the native population were adopting glass vessels. Though there are likely to have been immi-

27 The EVE values for these sites are given in the relevant entries in Appendix 1.

28 The order of the sites (cf. n.24) is: Wilcote, Carlisle 70-105, Caerleon TS 74-100, Gloucester 79-98, Chester 70-120, York 70-120, Colchester 65-150, Wroxeter 80-150, Caersws, London 75-90, Dorchester 70-150.

For a definition of quality see Baxter (supra n.20) 117. 
grants amongst the population of coloniae such as Colchester, the civitas capitals such as Wroxeter and Dorchester are more likely to have had a high native element in their population. These, it appears, adopted proportionally more of the drinking vessel/jug aspect of the vessel assemblage and less of the container aspect represented by the bottles. Presumably they were adopting the aspect of this new kind of material culture that best fitted their needs namely, the tablewares connected with drinking. Given that bottles form a proportionately smaller part of the assemblage on urban sites than on military ones, this may imply that the urban population had less use for the range of goods being transported and stored in them than the army. Unfortunately, it is not known precisely what the common bottles of the 1st and 2nd c. habitually contained, but it is probably safe to assume these were frequently items of food and drink. Possibly the urban population, while happy to adopt the tablewares, was less eager to adapt their diet in the 1st-early 2 nd c.

The presence of the only rural civilian site in the same area of the plot as the military sites possibly hints that there is not just an urban/military dichotomy in the use of glass vessels but also an urban/rural one. The problem of obtaining large samples from rural sites makes it difficult to explore this quantitatively. Many rural sites of this date have not been published in detail, but the 'interesting' fragments are frequently itemised. These are often concentrated amongst bowls, cups and beakers at the expense of more utilitarian containers, though the presence of bottles is frequently mentioned. It is possible to offer a crude quantification in the form of a comparison between the minimum number of bowls and minimum number of cups and beakers. This has been done by identifying the common later 1st-mid 2nd c. bowl, cup and beaker types ${ }^{30}$ published from a number of villa sites, and the results are presented in Table $3 .^{31}$ Although it must be stressed again that this is only a crude quantification, it is interesting that, with two exceptions, bowls tend to be in a majority, especially when one of those exceptions is Fishbourne which is more a palace than a typical rural villa. It is also possible to quote a number of rural sites where later 1st-mid 2 nd c. bowls are found but there are no examples of contemporary cup and beaker forms, whereas the opposite case is less common. In some cases, such as Northchurch, Herts, ${ }^{32}$ Fowler, Oxon., ${ }^{33}$ and Spong, Norfolk, ${ }^{34}$ these bowl fragments are of brightly coloured millefiori glass, and it could be argued that the bowl, or perhaps just the

30 For bowls the common forms are pillar moulded bowls, Isings Form 3, cast bowls especially those with wide rims, Colchester 37, and tubular rimmed bowls, Isings Forms 44 and 45 . For drinking vessels facetcut beakers and the other related externally-ground beakers and cups, Isings Form 21, indented and arcaded beakers, Isings Forms 32 and 33, and colourless wheel-cut beakers, Colchester 79.

31 The data are derived as follows. Fishbourne: D. Harden and J. Price, "The glass," in B. Cunliffe, Excavations at Fishbourne, 1961-1969. II. The finds (RepSocAnt 27, 1971) 317-68 (excluding the material found in the earlier Period 1 and Period 2 construction levels). Gadebridge Park: D. Charlesworth, "The glass," in D. Neal, The excavation of the Roman villa in Gadebridge Park, Hemel Hempstead 1963-8 (RepSocAnt 31, 1974) 203-7. Gorhambury: Neal et al. (supra n.23). Lullingstone: Cool and Price (supra n.22). Shakenoak: D. Harden, "The glass," in A. Brodribb, A. Hands and D. Walker, Excavations at Shakenoak Farm, near Wilcote Oxfordshire I (Oxford 1968) 74-81; id., "Glass," in A. Brodribb, A. Hands and D. Walker, Excavations at Shakenoak Farm, near Wilcote Oxfordshire II (Oxford 1971) 98-108; id., "Glass," in A. Brodribb, A. Hands, and D. Walker, Excavations at Shakenoak Farm, near Wilcote, Oxfordshire IV (Oxford 1973) 98-107. Whitton: J. Price, "The glass," in M. Jatrett and S. Wrathmell, Whitton, an Iron Age and Roman farmstead in South Glamorgan (Cardiff 1981) 152-62. Winterton: D. Charlesworth, "Glass," in I. Stead, Excavations at Winterton Roman villa and other Roman sites in North Lincolnshire 1958-1967 (Dept. Env. Arch. Rep. 9, 1976) 244-50.

32 D. Charlesworth, "The glass," in D. Neal, "Three Roman buildings in the Bulbourne valley," Hertfordshire Archaeology 4 (1974-6) 31 no. 11.

33 T. Allen "Excavations at Bury Close, Fowler, Oxon.," Oxoniensia 53 (1988) 304, fig. 7.4.

34 J. Price and H. Cool, "Objects of glass," in R. Rickett, The Anglo-Saxon cemetery at Spong Hill, North Elmham, VII: the Iron Age, Roman and early Saxon settlement (East Anglian Archaeology 73, 1995) 87 no. 1. 
fragment, arrived on the site as a novelty or keepsake. On other sites, though, the bowl fragments are of plain blue/green or lightly tinted glass and there seems no reason why they should be on the site for any purpose other than to be used as a vessel. Examples of these may be cited from Chiddingfold, Surrey, ${ }^{35}$ Hemel Hempstead, Herts, ${ }^{36}$ Baldock, Herts, ${ }^{37}$ Bletsoe, Beds., ${ }^{38}$ and Atworth, Wilts. ${ }^{39}$

There seems to be a distinct possibility that on rural sites in the later 1st and earlier 2nd c. glass vessels, though uncommon, were being used in a manner more akin to that operating on contemporary military sites than that on contemporary urban ones. Why this should be so is puzzling, as the military could scarcely have been direct rôle-models for the use of glass vessels on these rural sites. With the exception of Whitton, there would not have been a military presence in the vicinity of the sites quoted. One possibility is that people on the rural sites had some experience of military life and the way they were using the vessels reflected this. It has been suggested ${ }^{40}$ that some aspects of villa architecture at this time and the not infrequent finds of military equipment on villa sites reflect periods that the native villa-owning élite spent serving in the army. Perhaps the pattern of glass use on the sites is another aspect of the habits they brought back from this service.

$\begin{array}{lrc}\text { TABLE 3: INCIDENCE OF LATER 1st TO MID 2nd c. } \\ \text { BOWLS AND DRINKING VESSELS } \\ \text { ON SELECTED RURAL SITES } \\ \text { Site } & \text { Bowl } & \text { Beaker/cup } \\ \text { Fishbourne, W. Sussex } & 13 & 12 \\ \text { Gadebridge, Herts. } & 3 & 1 \\ \text { Gorhambury, Herts. } & 16 & 6 \\ \text { Lullingstone, Kent } & 3 & 1 \\ \text { Shakenoak, Oxon. } & 6 & 8 \\ \text { Whitton, S. Glamorgan } & 5 & 2 \\ \text { Winterton, N. Lincs. } & 4 & 0\end{array}$

When the assemblages of the mid 2 nd-3rd c. are examined, a different picture emerges. Figure 7 is the CA plot of the assemblages of that date given in Table 2, excluding the Caerleon bath-house (rows 12 to 23 and 25), together with a small assemblage from the fort at Chesterholm. ${ }^{41}$ The sites have been labelled according to whether they come from auxiliary forts (A), legionary fortresses (L), major towns (T), small urban centres (S), or other categories (O). ${ }^{42}$ As can be seen, there does not appear to be such a clear-cut separation of military and civilian sites. What is apparent is that there are two unusual small urban sites on the left of the plot (Harlow and Towcester) and possibly two unusual auxiliary assemblages in the top left (Housesteads) and bottom right (Rocester).

35 J. Arthur, "Catalogue of the glass," in T. Cooper, J. Gower and M. Gower, "The Roman villa at Whitebeech, Chiddingfold: excavations in 1888 and subsequently," Surrey Arch. Coll. 75 (1984) Mf p.32 no. 1.

36 Charlesworth (supra n.32) 117.

37 D. Charlesworth, "The glass," in I. Stead and V. Rigby, Baldock, the excavation of a Roman and pre-Roman settlement, 1968-72 (Britannia Monograph 7, 1986) 193 nos. 887-88.

$38 \mathrm{H}$. Cool, "Notes on the Roman glass from Bletsoe," in M. Dawson, A late Roman cemetery at Bletsoe, Bedfordshire (Bedfordshire Arch. Monograph 1, 1994) 56 no. 1.

39 Unpublished. We are grateful to J. Erskine for access to the glass from his excavations.

40 E. Black, "Villa-owners: Romano-British gentlemen and officers," Britannia 25 (1994) 100-10.

41 The EVE values for the site are given in Appendix 1.

42 The order of the sites (cf. n.24) is: Harlow 160-70, Towcester 155-65, Wroxeter 175-225, Housesteads 150-200, York 175-250, Lincoln 160-230, Verulamium 150-60, Pentre Farm 120-200, Rocester 140-200, Chesterholm, Caerleon TS 130-200, York 160-280, Castleford 140-180. 

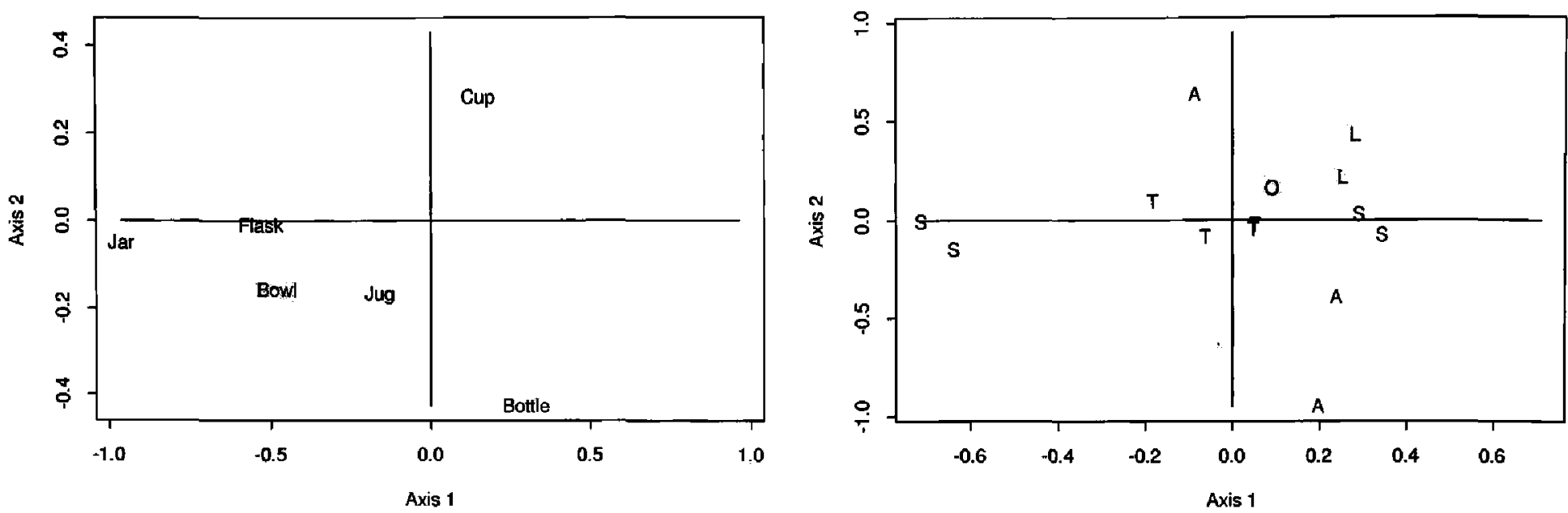

Fig. 7. Correspondence Analysis plot of 2 nd-3rd c. assemblages ( $45 \%$ of the inertia accounted for by the first axis, $32 \%$ by the second).

Harlow and Towcester are characterised by a relatively high proportion of jars and account for nearly $70 \%$ of the inertia on the first axis. These pit groups are unusual not only in their composition but also because substantial parts of vessels are present in the pits rather than the small fragments usually found on domestic sites. It is possible that these two deposits reflect some sort of domestic accident that escaped re-cycling, but it is equally possible that they are part of the phenomenon of ritual deposition of apparently ordinary domestic material in pits that is being increasingly recognised on Romano-British sites. ${ }^{43}$ Certainly the Towcester pit contained many nearly-complete pottery vessels, ${ }^{44}$ one of the defining features which Merrifield ${ }^{45}$ suggested should alert us to the possibility that we are not dealing with ordinary rubbish. If the Harlow and Towcester assemblages are omitted and a second correspondence analysis carried out, Rocester and Housesteads are confirmed as being unusual, between them accounting for just over half the inertia on the first axis.

The plot suggests that the status of individual sites may be increasingly influencing the composition of the glass assemblage derived from them, rather than the urban/military contrast that was suggested for the earlier period. This is easiest to explore amongst the military assemblages. The assemblages from Rocester and Housesteads are obviously very different despite both coming from auxiliary forts. Within the forts, however, the Housesteads assemblage comes from the commandant's house while that from Rocester came from the barracks. The other barrack assemblage from an auxiliary site (Chesterholm) is also in the same area of the plot as Rocester. The two legionary assemblages (Blake St. York and Caerleon), by contrast, plot broadly together in the upper right-hand side of the plot. Both of the legionary assemblages appear to derive from high-status buildings within the fortresses. It could be suggested that people of different status were tending towards using different suites of vessels. Put simply within the context of these analyses, the officers tended towards drinking vessels, and the men towards bottles.

Other officials may have tended to use similar suites of glass vessels. Pentre Farm is thought to have been an official residence, possibly of a procurator and thus an individual of

43 R. Merrifield, The archaeology of ritual and magic (London 1987) 30-36; S. Clarke and R. Jones, "The Newstead pits, ${ }_{r}$ in C. van Driel-Murray (ed.), Military equipment in context = JRMES 5 (1994 [1996]) 109-24. For other substantial parts of glass vessels deposited in possibly similar circumstances in the mid 2nd c., see H. Cool and C. Philo (edd.), Roman Castleford excavations 1974-85. I. The small finds (Yorkshire Archaeology 4, 1998) 362.

44 G. Lambrick, "Excavations at Park Street, Towcester," Northamptonshire Archaeology 15 (1980) 45.

45 Merrifield (supra n.43) 188. 
similar status to an auxiliary commander or a senior (though not commanding) officer of a legion. On fig. 7 it plots close to the origin and is thus not well represented, but on a CA plot which excludes Harlow and Towcester and their distorting effect, it was found to plot close to the Caerleon legionary assemblage. At the auxiliary fort of Segontium a large courtyard building of Antonine to $3 \mathrm{rd} \mathrm{c}$. date has been interpreted as the residence of a procurator. ${ }^{46} \mathrm{In}$ a drain associated with its use, a small assemblage of glass vessel fragments was recovered which again concentrate on tablewares, especially ones that could be drunk from. As published, ${ }^{47}$ there are two rim fragments clearly from beakers (EVE 0.6), the complete profile of a conical bowl (EVE 1.0), three rim fragments of either bowls or large cups/beakers (EVE 1.0), and bottle fragments with an EVE value of 0.7. The bowls are unusual forms and could easily have functioned as large drinking vessels.

The difference between major urban centres and other civilian settlements seems to continue at this period. If the possibly ritual assemblages from Harlow and Towcester are ignored, there appears to be a separation between the larger urban centres that cluster around the origin and smaller urban centres to the right of fig. 7. The smaller centres of Castleford and Catterick have assemblages which are proportionately higher in drinking vessels and bottles, than the assemblages from the civitas capitals and coloniae which seem to have more mixed assemblages, as they had done earlier. The smaller urban sites and rural sites continue to suffer from the problems of size of assemblage and quality of reporting noted earlier, so confirming this suggestion quantitatively is difficult. It can, however, be noted that small assemblages of this date from the smaller urban centres frequently consist mainly of drinking vessels with some bottle fragments. Examples of this can be cited from Ilchester, Somerset, ${ }^{48}$ Neatham, Hants. ${ }^{49}$ Malton, N. Yorks. ${ }^{50}$ A similar phenomenon is also noted on rural sites such as Cosgrove, Northants, ${ }^{51}$ Poundbury, Dorset, ${ }^{52}$ and Peartree Farm, Bedford ${ }^{53}$

\section{4th-c. assemblages}

Table 4 summarises the 4 th-c. assemblages from 19 sites. As the data have been collected on typological rather than stratigraphic grounds (see above p. 74), these assemblages are related to broad categories of sites, rather than to particular buildings or episodes, as was possible for some of the 1st-3rd c. ones. The categories include major urban sites (Colchester, Dorchester, Gloucester, Winchester, Wroxeter), minor urban sites (Bath, Towcester), rural sites (Atworth, Barnsley Park, Frocester Court, Stanwick, Dalton Parlours, Claydon Pike, Uley) and military sites (Caister, Portchester, York). In part the different collection criteria permit the incorporation of more data from rural sites, but the increased number of rural assemblages in this analysis compared to those of the 1st-3rd c. does seem to reflect an increased use of vessel glass on these sites in the 4 th $c$.

46 P. Casey and J. Davies, Excavations at Segontitum (Caernarfon) Roman fort, 1975-1979 (CBA Res. Rep. 90, 1993) 13-14.

47 D. Allen in Casey and Davies, ibid. 220 nos. 10-15, 224 nos. 40-41.

48 J. Price, "The Roman glass," in P. Leach, Ilchester 1. Excavations 1974-5 (Western Arch. Trust Monograph 3, 1982) 228 nos.11-16, 230 no. 18.

M. Millett and D. Graham, Excavations on the Romano-British small town at Neatham, Hampshire 19691979 (Hampshire Field Club Monograph 3, 1986), especially the small assemblage associated with the mid 3rd-c. defences, 121 nos. 321-24, and other late 2nd-3rd c. contexts, 121 nos. 333 and 376.

50 J. Price and S. Cottam, "The Roman glass," in L. Wenham and B. Heywood, The 1968 to 1970 excavations in the vicus at Malton, North Yorkshire (Yorkshire Arch. Rep. 3, 1997) 118-27.

51 J. Price, "Roman glass," in $\mathrm{H}$. Quinnel "The villa and temple at Cosgrove, Northamptonshire," Northamptonshire Archaeology 23 (1991) 31-34.

52 C. Green, Excavations at Poundbury, Dorchester, Dorset 1966-1982. I. The settlements (Dorset Nat. Hist. \& Arch. Soc. Monograph 7, 1987) 109.

53 Unpublished: Bedford southern by-pass excavations. 
In two of the major urban sites (Colchester and Winchester) it is possible to divide the assemblage between that found within the walls and that from suburban sites immediately outside. As it has been noted ${ }^{54}$ that contemporary coin assemblages from sites immediately outside town walls are more similar to those from rural sites than from intramural sites, it seems appropriate to use this distinction here. All of the other major urban site assemblages are from intramural sites.

TABLE 4: COMPARISON OF 4th c. ASSEMBLAGES

\begin{tabular}{lrllllr}
\multicolumn{1}{c}{ Site } & \multicolumn{1}{c}{ Cup } & Bowl & Flask & Jug & Bottle & Total EVE \\
Caister & 25.80 & 0.80 & 0.80 & 0.70 & 1.84 & 29.94 \\
Portchester & 6.00 & 1.40 & 0 & 0.84 & 0.14 & 8.38 \\
York & 10.00 & 3.00 & 0.20 & 0.70 & 0.98 & 14.88 \\
Colchester intramural & 7.40 & 2.80 & 0.42 & 0.60 & 0 & 11.22 \\
Colchester extramural & 1.80 & 0.40 & 0.60 & 0.84 & 0.61 & 4.25 \\
Dorchester & 5.00 & 2.80 & 0 & 0.84 & 1.36 & 10.00 \\
Gloucester & 5.40 & 1.80 & 0 & 0.42 & 0.14 & 7.76 \\
Winchester intramural & 9.00 & 2.00 & 0.20 & 0.56 & 0.98 & 12.74 \\
Winchester extramural & 1.20 & 0 & 0.40 & 0.70 & 0.58 & 2.88 \\
Wroxeter & 24.20 & 2.60 & 1.80 & 4.13 & 2.32 & 35.05 \\
Towcester & 9.40 & 0 & 0.07 & 1.18 & 1.27 & 11.92 \\
Atworth & 3.20 & 0.20 & 0.20 & 0.14 & 0.14 & 3.88 \\
Barnsley Park & 4.80 & 1.20 & 0.07 & 0.70 & 1.13 & 7.90 \\
Dalton Parlours & 2.00 & 0 & 0 & 0.28 & 0.07 & 2.35 \\
Frocester & 3.60 & 1.40 & 0 & 1.96 & 0.59 & 7.55 \\
Stanwick & 8.73 & 1.80 & 0.27 & 1.47 & 1.47 & 13.72 \\
Claydon Pike & 3.44 & 0 & 0 & 1.00 & 0.44 & 4.88 \\
Bath & 6.20 & 1.00 & 0 & 0.42 & 0 & 7.62 \\
Uley & 5.00 & 1.00 & 0.40 & 0.77 & 0.32 & 7.49
\end{tabular}
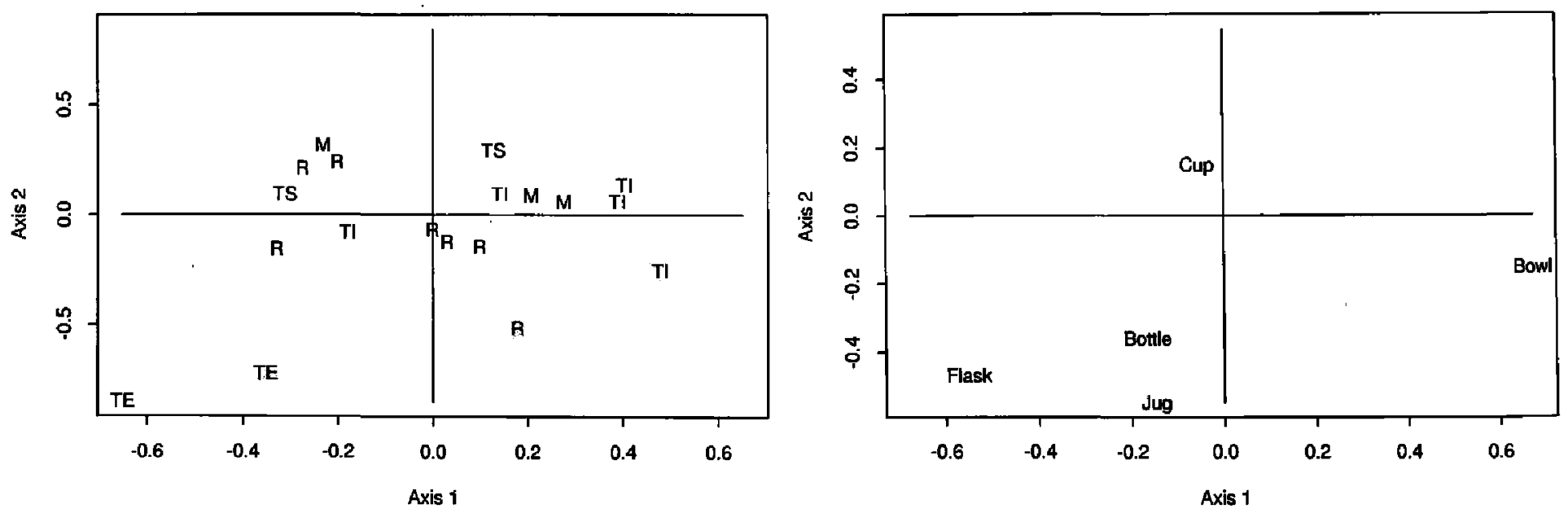

Fig. 8. Correspondence Analysis plot of 4th c. assemblages ( $40 \%$ of the inertia accounted for by the first axis, $36 \%$ by the second).

As is to be expected, drinking vessels form a substantial part of each assemblage, only dropping to $c .50 \%$ or less on two sites (the extramural ones). On the CA plot of the data (fig. 8$)^{55}$ the

54 R. Reece, "Site-finds in Roman Britain," Britannia 26 (1995) 203, fig. 28.

55 The order of the sites (cf. n.24) is: Winchester extramural, Colchester extramural, Claydon Pike, Tow- 
sites have been labelled according to whether they are major urban intramural (TI) or extramural (TE), small towns (TS), military sites (M), and rural sites (R). The two extramural sites are in a different part of the plot from the other sites and are characterised by a high proportion of the closed forms (flasks, jugs, bottles). For the rest of the assemblages there are no clearcut divisions between the different categories of sites. It is possible to characterise the assemblages in other ways such as religious (Bath, Claydon Pike, Uley) and secular, northern and southern or eastern and western sites, but these ways of describing the data do not help in identifying any patterns, in the same way that it was possible to see patterns in the 1st-3rd c. plots.

An inspection of the column plot, however, does suggest a more pronounced opposition of closed and open forms than is apparent for the earlier periods. If the row plot is inspected from this aspect, then there is a tendency for the urban (intramural) and military sites to have a lower proportion of closed forms than the rural sites, with the extramural sites having the highest proportion of the closed forms. The two small towns seem to mirror the pattern of the larger urban centres, the one with the highest proportion of open forms being an intramural site (Bath) and that with the lowest being a suburban site (Towcester). It would appear, therefore, that glass vessels continue to be used differently in urban and rural contexts in the 4 th c., just as they had been earlier. In the case of the 2nd-3rd c. assemblages it was suggested (above p. 87) that those from small towns might be more similar in their functional composition to those from rural sites. This analysis suggests that by the 4 th $c$. glass vessel usage in the smaller urban sites might have been more similar to that in coloniae and cioitas capitals. It should be noted though that, with drinking vessels so dominant in most assemblages, such differences are muted.

\section{Regionality and Flavian drinking vessels}

We have concentrated on tracing the major functional differences in the types of glass vessels used through time and on different categories of sites, but other factors are also likely to have played a part in the precise kind of vessels used. One of these is likely to have been the part of Britain where the site was located, as it is becoming increasingly clear that Roman Britain was not a single entity but a patchwork of different regions, then ${ }^{56}$ as now. All of the analyses reported have been inspected to see if regionality is playing a rôle in structuring the data, but it was not detected. This is probably because it has not been possible to obtain sufficient contemporary assemblages from a single category of site - for example, major urban centres - for them to emerge from the masking effects of time and type of site.

\section{TABLE 5: COMPARISON OF FLAVIAN DRINKING VESSELS}

$\begin{array}{lllllllllll}\text { Site } & \text { Date } & \text { N-S order } & \text { Sport } & \text { Tall } & \text { Rib C } & \text { Hof C } & \text { Ind B } & F-c B & \text { W-c B } & \text { Total EVE } \\ \text { Carlisle } & 71-105 & 1 & 0.8 & 0.2 & 1.0 & 0 & 0.2 & 0.2 & 0.4 & 2.8 \\ \text { York } & 71-100 & 2 & 0 & 0 & 0.2 & 2.2 & 0 & 0 & 0.6 & 2.4 \\ \text { Castleford } & 71-100 & 3 & 0 & 0.4 & 1.4 & 0 & 0.2 & 0.2 & 0.2 & 2.4 \\ \text { Wroxeter } & 80-120 & 4 & 0 & 0 & 0.6 & 0.4 & 0 & 0.2 & 0.2 & 1.4 \\ \text { Caersws } & 69-100 & 5 & 0 & 0.2 & 0.6 & 2.2 & 0 & 0 & 0 & 3.0 \\ \text { Colchester } & 65-100 & 6 & 0.8 & 0 & 0 & 2.4 & 0.6 & 0.4 & 0.2 & 4.4 \\ \text { Gloucester } & 70-98 & 7 & 0 & 0.6 & 0 & 2.8 & 0 & 0 & 0 & 3.4 \\ \text { Caerleon } & 74-100 & 8 & 0 & 0 & 0 & 1.2 & 1.0 & 1.8 & 0.8 & 4.8 \\ \text { London } & 65-100 & 9 & 2.0 & 1.0 & 0 & 2.8 & 3.0 & 3.2 & 1.0 & 13.0 \\ \text { Fishbourne } & 75-100 & 10 & 0 & 0.2 & 0 & 0 & 0.4 & 0.8 & 0 & 1.4\end{array}$

cester, Dalton Parlours, Caister, Atworth, Wroxeter, Uley, Stanwick, Barnsley Park, Bath, Winchester intramural, Frocester Court, Portchester, York, Colchester intramural, Gloucester, Dorchester. 
The geographical interpretation of this plot seems a compelling one, as assemblages from sites of the same category are in different areas of the plot if they are in different geographical areas. For example, the two legionary fortress assemblages from forts founded at about the same time, York (site 2) in the north and Caerleon (site 8) in the south plot differently, as do the major urban centres of Wroxeter (site 4) in the Midlands and Colchester and London (sites 6 and 9) in the south. The types that are characteristic of the northern and Midlands sites are the ones that were already in use in the Claudio-Neronian period and which are generally thought of as going out of use in the early Flavian period. The characteristic southern forms, by contrast, are the newly-introduced Flavian forms. Intuitively, one would have expected the opposite to be the case, for traditionally the Claudio-Neronian forms in the north are viewed as isolated survivals. ${ }^{66}$ The analysis suggests this view may not be correct, and that the presence of the Claudio-Neronian forms in the north may be the rule rather than the exception. One interpretation of the pattern could be that there were problems of supply and that the newer forms were simply not reaching the sites in the Midlands and the north. Though a possibility, this seems unlikely as similar problems could be expected to affect other categories of material, such as samian pottery, and we are not aware of suggestions to this effect. The samian pottery from York, for example, has been extensively surveyed, ${ }^{67}$ and it is not until the Trajanic period that the supply of contemporary forms declined. An alternative interpretation may lie in the shapes of the vessels. The ones more favoured on the northern/Midland sites are low cups, whilst those on the southern sites are tall beakers. Any beer-drinker in England today is familiar with the fact that regional preferences in pint glasses still survive, with the 'straight' glass of the north and the handled 'jar' of the south. Perhaps the pattern seen in fig. 9 is a 1st-c. reflection of a similar phenomenon.

\section{The wider picture}

Thus far glass vessels have been looked at in isolation, but they were used as part of a suite of vessels made in a variety of materials, including pottery, metal, wood and probably horn. Any attempt to interpret the patterns seen in the glass vessels must take into account the vessels in other materials, of which pottery is the only category usually available for comparison; metal vessels would have been long-lasting and, when finally beyond repair, would have been re-cycled; and the vessels of inorganic material suffer from problems of survival. There are, however, methodological problems in comparing glass and pottery assemblages because, as with glass, the quantification and full publication of pottery assemblages has only recently become a standard to aspire to. In pottery studies there has also been the problem that considerations of fabric rather than form have often been favoured. ${ }^{68}$ In this section an attempt is made to set the patterns observed in the glass assemblages within the wider context of other categories of material, especially pottery. This can only be a preliminary and brief statement, but it may serve to highlight areas where future work could usefully concentrate.

The dominant pattern in the use of glass vessels is the progressive rise in the vessel forms that are likely to have served as drinking vessels (cups and beakers). They rise at the expense of most closed vessels, with the exception of jugs; those seem only to have declined slightly as a proportion of most assemblages by the 4 th c. (Table 1). A simple explanation might be that there was a corresponding rise in the numbers of closed vessels in other materials to compensate.

J. Price, "Roman vessel and window glass," in M. McCarthy, A Roman, Anglian and Medieval site at Blackfriars Street, Carlisle excavations 1977-9 (Cumberland \& Westmorland Ant. \& Arch. Soc. Res. Ser. 4, 1990) 166.

67 B. Dickinson and K. Hartley, "The evidence of potters' stamps on samian ware and on mortaria for the trading connections of Roman York," in R. Butler (ed.), Soldier and civilian Roman York (Leicester 1971) 131; B. Dickinson, "Samian," in J. Monaghan, Roman pottery from York (The Archaeology of York 16/8, 1997) 943. 
In pottery this does not appear to be the case. On sites where pottery has been quantified by form rather than fabric, flagons form a smaller proportion of the assemblage from the 3rd c. than they had earlier. This may be observed at Verulamium, ${ }^{69}$ Chelmsford, ${ }^{70}$ York, $^{71}$ and a variety of other northern sites. ${ }^{72}$ Indeed, when this pattern was observed in the pottery assemblage from Exeter, it was suggested that they had been superseded by glass or metal vessels! ${ }^{73} \mathrm{~A}$ rise in metal jugs or flagons might be a possibility, though, as these would have belonged to the more expensive end of the market, they can scarcely have been an option for the poorer members of society. The late Roman period admittedly did see the rise of the pewter vessel industry, ${ }^{74}$ which included jugs amongst its wares and which might be seen as a cheaper option to other metal vessels. However, any suggestion that pewter vessels filled the flagonshaped 'hole' in the overall vessel assemblage in the late Roman period should be treated with caution. The majority of pewter vessels have been found in contexts that strongly suggest ritual deposition, ${ }^{75}$ and the scarcity of fragments in ordinary site assemblages must cast doubt on the theory that they were regularly part of utilitarian table services.

It must be a distinct possibility that closed forms in all materials were less common in the later Roman period than earlier. Closed forms such as bottles, flasks, and jugs were a part of the vessel assemblage that had been introduced with the incorporation of Britain into the empire. The late Iron Age population in the parts of Britain that had used ceramics had used jars, beakers, and shallow dishes. ${ }^{76}$ It could be that large parts of the Romano-British population were returning to a cooking, eating, and dining régime that had more in common with the late pre-Roman Iron Age norms than the Early Roman ones. Closed vessel forms could be seen as symptomatic of a flirtation with Roman ways that was ultimately rejected. This makes the pattern seen in the 4 th-c. glass assemblages - where, if anything, it is the rural sites that retain a slight preference for closed forms - intriguing. Could it be that it was in the villas that 'Roman' standards were maintained?

One of the themes that emerges from the glass vessels is that a good case can be made for a continuing difference in the way in which they were used in the countryside and in the major towns. This goes beyond the fact that glass is scarcer on most rural sites than it is on most urban and military sites. Rural assemblages are not just scaled-down urban ones but they favour different shapes of vessels, implying they were used for different functions.

One type of find where there has been extensive work on exploring the nature of assemblages found on different types of sites is coinage. The fact that coins come with built-in dating has enabled a large volume of data to be gathered and different categories of urban settlement to be defined. A difference throughout the Roman period can certainly be seen between the assemblages from villa sites and what Reece has termed the 'good towns'. ${ }^{77}$ Again, this is not just a case that villas have scaled-down versions of urban and military site assemblages, but reveals different patterns of supply, loss, and presumably use. A survey of the use of pottery in northern

69 M. Millett, "An approach to the functional interpretation of pottery," in M. Millett (ed.), Pottery and the archteologist (Inst. of Arch. London Occ. Pap. 4, 1979) fig. 13.

70 C. Going, The mansio and other sites in the south-eastern sector of Caesaromagus: the pottery (CBA Res. Rep. 62, 1987) Table 10.

71 Monaghan (supra n.67) 855.

72 J. Evans, "Pottery function and finewares in the Roman north," Journal of Roman Pottery Studies 6 (1993) Appendix 1. The figure for flagons falls from a mean of $7 \%$ in 2 nd-c. assemblages to one of $2.5 \%$ for late 4 th-c. assemblages.

73 N. Holbrook and T. Bidwell, Roman finds from Exeter (Exeter Arch. Rep. 4, 1991) 139.

74 N. Beagrie, "The Romano-British pewter industry," Britannia 20 (1989) 169-91.

75 R. Poulton and E. Scott, "The hoarding, deposition and use of pewter in Roman Britain," in E. Scott (ed.), Theoretical Roman Archaeology: First Conference Proceedings (Aldershot 1993) 115-32.

76 Millett (supra n.69) 39.

77 R. Reece, "British sites and their Roman coins," Antiquity 67 (1993) 863-69, esp. fig. 1. 
Britain also revealed that the functional composition of urban and rural assemblages is noticeably different, especially in the 2 nd and later 4 th $c^{78}$ This is especially interesting as, in the north of Britain, pottery itself is a new introduction associated with the coming of Rome. Prior to that the area was aceramic. So, as with glass vessels, a difference in the way rural and urban native populations adopted a new form of material culture can be observed. The coins, the glass vessels, and the pottery all point to the same story: that an individual's experience of living in Roman Britain would be very different depending on whether one lived in a town or in the courtryside.

The simple explanation, that it lies in the economic realm, and that country-dwellers had less access to the full range of romanised goods, is increasingly unlikely. Detailed studies on the presence of samian, the romanised pottery type par excellence of the 1st and 2nd c., show that, though it is not plentiful on rural sites, it is repeatedly found at all levels of the settlement hierarchy. ${ }^{79}$ The explanation seems to lie instead at a more fundamental level of choices about which elements of romanised goods the country dwellers had a use for. The disproportionate number of glass bowls on late 1st-2nd c. rural sites, for example, is inexplicable from an economic point of view. The tubular-rimmed form that is commonly found ${ }^{80}$ on rural sites is part of a suite that includes globular and conical jugs and collared jars all made in a similar range of colours, decorated in a similar manner, and very likely coming from the same glass-houses. ${ }^{81}$ On urban and military sites the jugs and jars are as common as the bowls, and it is very difficult to imagine any situation where rural dwellers would have access to the bowls but not the jugs and jars. Instead, the bowl element was deliberately chosen, possibly for the same reasons that large decorated samian bowls seem to form a disproportionately large part of the pottery assemblage on contemporary rural sites. ${ }^{82}$ Large-scale studies of Roman Britain frequently use the opposition of town and country as a way of structuring their material but this is generally on the level of building types and services available; the smaller items of material culture such as coins and vessels suggest that the differences may be far more fundamental than this, and it is certainly an area where more work has to be done.

The vessel glass assemblages of the later 1st-2nd c. showed a difference between those on forts and those in towns, and it was suggested that this might be reflecting a difference in diet, with the urban population using less of the foodstuffs contained in the bottles that are such a feature of many military sites. To put the vessel glass in perspective the obvious object to study is the amphora, the bulk transport-container for many of the items that may have been decanted into the bottles. There are, however, problems in looking at the volume of amphorae on sites. One is methodological: it is difficult to quantify them and so it is rarely done. The other is a depositional problem: amphorae were frequently discarded at the point where their contents were decanted, and this was generally not at the point where the contents were used. Monte Testaccio, the huge mound of Spanish amphorae sherds by the Tiber at Rome, is the classic example, but it can also be seen at London where the largest amounts of amphorae are found in the port area, ${ }^{83}$ and a similar pattern is seen at York. ${ }^{84}$

$78 \quad$ Evans (supra n.72) figs. 7 and 13.

79 K. Griffiths, "Marketing of Roman pottery in second-century Northamptonshire and the Milton Keynes area," Joumal of Roman Pottery Studies 2 (1989) 76; P. Booth, "Inter-site comparisons between pottery assemblages in Roman Warwickshire: ceramic indicators of site status," Journal of Roman Pottery Studies 4 (1991) figs. 2-4.

80 See supra rn. 35-39.

81 Isings Forms 52, 55 and 67c; Colchester 106-9, 120-30.

82 S. Willis, "Samian: beyond dating," in K. Meadows, C. Lemke and J. Heron (edd.), TRAC 96. Proceedings of the Sixth Annual Roman Archaeology Conference (Oxford 1997) 41.

83 B. Davies "Inter-site studies," in G. Milne and A. Wardle, "Early Roman development at Leadenhall Court, London and related research," TransLonMiddxArchSoc 44 (1993 [1996]) 140.

84 Monaghan (supra n.67) 858. 
As an alternative to amphorae, the incidence of mortaria can be used, for they reflect a romanised cuisine from the point of view of the utensil rather than the ingredient. Again, there are problems in obtaining quantified comparanda, but such that there are also point to a difference between military and urban practices. In the legionary fortresses at York and Chester, mortaria form 3.5-4\% of assemblages during the later 1st to early $2 \mathrm{nd} \mathrm{c.}{ }^{85}$ At Leadenhall Court, London, the figure is $2.3 \%,{ }^{86}$ but at Chelmsford and Dorchester (which are probably more typical of the bulk of urban sites) the figure drops to $c .1 .5 \%$ and $0.6 \%$ respectively. ${ }^{87}$ In the light of this, the presence of mortaria that is often noted on rural sites ${ }^{88}$ may be significant. It might be additional evidence that in the early Roman period the countryside might have had more links with military modes of behaviour than urban ones. The study of what different groups ate and drunk is an under-exploited avenue for the investigation of romanization, and the vessels used in preparation and consumption could provide useful information.

We are aware that this paper has only scratched the surface of the story that vessel glass assemblages can tell. We would be the first to agree that in an ideal world more tightly focussed assemblages would have been preferred, but this is the real world and this is the type of data that is available. We hope, however, that we have shown that fully quantified assemblages provide a rich source of information and are well worth publishing. As the volume of such data increases, more detailed and focussed analyses will become possible and the investigation of topics such as regionality will become possible. Ideally, the comparison of assemblages will not remain barricaded within artificial specialities such as glass or pottery studies, but will develop so that it encompasses a wide range of the material culture that is found on sites. Correspondence Analysis promises to be a useful tool in this work. It has already been used for comparing small finds assemblages, ${ }^{89}$ and could be used for pottery assemblages quantified by EVEs. ${ }^{90}$ Animal bone assemblages are also starting to be compared statistically in a similar way with useful results. ${ }^{91}$

Assemblage comparison promises to be a research tool of great value for archaeological research, but it does require the full and detailed publication of material from excavations. It should never be forgotten that the specialist reports banished to the rear of so many excavation reports (or, even worse, to the archive) are not so many optional extras: they are the very stuff of past lives and habits and should be treasured and used as such.

16 Lady Bay Road, West Bridgford, Nottingham NG2 5BJ (HC) Dept. of Maths., Stats. and O.R., Nottingham Trent Univ., Nottingham NG11 8NS (MB)

$853.5 \%$ of the assemblage by EVEs deposited between $c .71$ and 120 at Blake St., York: J. Monaghan, Roman pottery from the fortress (The Archaeology of York 16/7, 1993) Table $124.3 .9 \%$ of the assemblage by EVEs deposited between $c .71$ and 120 at Wellington Row, York: Monaghan (supra n.67) Table 211. $4 \%$ of the assemblage (by minimum numbers) deposited between 80 and 130 at Chester: Evans (supra n.72) Appendix 1 p.112.

86 J. Groves, "Function, status and Romanisation at Leadenhall Court," in Milne and Wardle (supra n.83) Table 13 (quantified by EVEs).

87 Chelmsford, quantified by EVEs and deposited between c.80 and 125: Going (supra n.70) Table 10. Dorchester, quantified by fragment numbers and deposited in the late 1st to early 2 nd c.: P. Woodward, S. Davies and A. Graham, Excavations at the Old Methodist Chapel and Greyhound Yard, Dorchester, 1981-1984 (Dorset Nat. Hist. \& Arch. Soc. Monograph 12, 1993) Table 44.

88 Evans (supra n.72) 100; Booth (supra n.79) figs. 2-3.

89 H. Cool, G. Lloyd-Morgan and A. Hooley, Finds from the Fortress (The Archaeology of York 17/10, 1995) 1638-43.

$90 \mathrm{M}$. Baxter and H. Cool, "Notes on some statistical aspects of pottery quantification," Medieval Ceramics 19 (1995) 95.

91 M. Moreno-Garcia, C. Orton and J. Rackham, "A new statistical technique for comparing animal bone assemblages," JArchSci 23 (1996) 437-53; C. Orton, "Dem dry bones," in J. Bird, M. Hassall and H. Sheldon (edd.), Interpreting Roman London (Oxbow Monograph 58, 1996) 199-208. 


\section{Acknowledgements}

We are very grateful to English Heritage who not only funded the project to develop a method of calculating EVEs for glass vessels, but also funded the post-excavation work which led to the cataloguing of many of the assemblages used in this paper. Of the unpublished reports these include work on the glass from Atworth, Carlisle, Catterick, Chester, Claydon Pike, Dorchester, Gloucester, Lincoln, Stanwick, and Wroxeter. We are also very grateful to all of the excavators and archaeological units who have allowed $H$. Cool to catalogue their glass over the years and who have provided the vital contextual information on which this paper depends. In alphabetical order these units are: Avon Archaeological Unit, Bedfordshire County Archaeological Service, Birmingham Univ. Field Archaeology Service, Carlisle Archaeology Unit, Central Archaeological Service, Chester Archaeological Service, City of Lincoln Archaeology Unit, Clwyd-Powys Archaeological Trust, Colchester Archaeological Trust, Norfolk Archaeological Unit, Trust for Wessex Archaeology, West Yorkshire Archaeological Service, Winchester Museums Service, and York Archaeological Trust. The Gloucester glass was studied by permission of $H$. Hurst and that from Wilcote by permission of A. Hands.

Although it is not normal to thank the authors of cited references, this paper could not have been written without the work of the other glass specialists who have catalogued and published groups of material drawn upon here. Special thanks are due to Denise Allen, Sally Cottam, Jenny Price, John Shepherd and David Zienkiewicz. The pioneering foundations of Roman glass studies in Britain laid by the late D. Harden and D. Charlesworth are also gratefully acknowledged.

\section{APPENDIX 1: THE GLASS ASSEMBLAGES USED HERE}

Where assemblages are described as unpublished they have been catalogued by $\mathrm{HC}$ urless otherwise noted. Atworth, Wilts. is a late Roman villa site. The 4th-c. assemblage in Table 4 comes from the unpublished excavations conducted by J. Erskine. ${ }^{92}$

Barnsley Park, Glos. is a villa site. It contributed a 4 th-c. assemblage to Table 4.93

Bath, Somerset was a small town that grew up around the major cult centre of the hot springs of Sulis Minerva. The 4th-c. assemblage in Table 4 comes from the precinct of the tempte. ${ }^{94}$

Caersws, Powys was the site of an auxiliary fort and vicus. The assemblage used in the analysis reported above on p. 83 came from the vicus and was recovered in contexts dating to Phases 1 and 2 (c.69-130), but there is the possibility that some Neronian material may be intrusive from make-up layers. ${ }^{95}$ The EVE values used in that analysis are as follows: drinking vessels 6.2 , bowls 3.0, jars 1.17, flasks 1.6, jugs 2.66, bottles 4.2. The drirking vessel assemblage in Table 5 comes from contexts belonging to Phase 1 .

Caerleon, Newport was a legionary fortress founded c.74-78 and it remained one of the three permanent legionary fortresses in Britannia. It contributes 4 assemblages to Table 2. Two of these (Caerleon TS) come from the excavations in the Scamnum Tribunorum; ${ }^{96}$ the first from contexts associated with Phase I to IIIa (c.74-100), the second to Phase IVb and V (c.130-200). The other two (Caerleon BH) came from drain deposits associated with the bath-house, ${ }^{97}$ the first from Drain group $1 b(c .80-100 / 110)$, the second from Drain group 4 (c.160-230). It should be noted that 166 additional bath flask fragments from Drain group 4 were

92 For earlier excavations at the site see A. Mellor and R. Goodchild, "The Roman villa at Atworth, Wilts.," Wiltshire Arch. Mag. 49 (1940) 46-95.

93 J. Price, "The glass," in G. Webster and L. Smith, "The excavation of a Romano-British rural establishment at Barnsley Park, Gloucestershire, 1961-1979, Part II c.A.D. 360-400+," TBGAS 100 (1982) 17485.

J. Shepherd, "Roman glass," in B. Cunliffe and P. Davenport, The Temple of Sulis Minerva at Bath, 1. The site (OUCA Monograph no. 7, 1985) 161-64.

$95 \mathrm{H}$. Cool and J. Price, "The glass vessels," in J. Britnell, Caersws vicus, Pourys. Excavations at the Old Primary School, 1985-86 (BAR Brit. Ser. 205, Oxford 1989) 31-43.

96 The site report is published in J. Zienkiewicz, "Excavations in the Scamnum Tribunorum at Caerleon: the Legionary Museum site, 1983-5," Britannia 24 (1993) 27-140. A fuller glass report is available in J. Zienkiewicz, "Roman glass vessels from Caerleon: excavations at the legionary museum site, 1983-5," The Monmouthshire Antiquary 8 (1992) 1-9, and I am grateful to J. Zienkiewicz for making his archive catalogue available to me. 
unquantifiable for this exercise, ${ }^{98}$ so the flask total is lower than it should be. The drinking vessel assemblage in Table 5 is derived from contexts dated to between 74 and 100 at these sites with the addition of material from similarly-dated contexts at the amphitheatre, ${ }^{99}$ the barracks at the 'Roman Gates' site, ${ }^{100}$ and the industrial area at Alstone Cottage. ${ }^{101}$

Caister, Norfolk was a coastal fort constructed in the early 3rd c. which became part of the later frontier system known as the Saxon Shore. It contributes a 4th-c. assemblage to Tables 1 and $4 .{ }^{102}$

Carlisle, Cumbria was a military base with both legionary and auxiliary troops present during the Flavian and early Trajanic periods. Thereafter the vicus developed into an independent small town. The glass considered comes from three published excavations at Blackfriars St., Castle St. and the Tullie House Lift shaft ${ }_{2}{ }^{103}$ and from currently unpublished excavations at Annetwell St. (excavations in 1973-79 directed by D. Charlesworth and in 1980-84 and 1989 directed by I. Caruana), and the The Lanes ${ }^{104}$ Carlisle contributes a mixed military and civilian assemblage dated $c .71 / 74-150$ to Table 1 , a military assemblage of $c .71 / 74-105$ to Table 2, and one of the same date to the drinking vessel assemblages of Table 5.

Castleford, W. Yorks, was a fort and vicus where the military occupation lasted $c .71 / 74-95 / 100$ and the civilian occupation lasted until the late 2 nd $c$. The garrison was primarily auxiliary though legionaries were present. Four assemblages have been extracted from the published data. ${ }^{105}$ That in Table 1 consists of the military occupation and the vicus occupation up to c.140. In Table 2 the assemblage dated to 71-100 comes from military contexts within the fort, and that dated 140-180 from civilian contexts in the vicus. The drinking vessel assemblage in Table 5 comes from the entire site.

Catterick, $N$ Yorks. The assemblage in Table 2 comes from the unpublished excavations at the roadside settlement at Bainesse Farm outside the military and civilian settlement at Catterick. The occupation at this site starts in the late Hadrianic-early Antonine period and continued into the $3 \mathrm{rd} \mathrm{c.}{ }^{106}$

Chester, Cheshire founded in 74-78 was one of the three permanent legionary fortress in Britannia. Two assemblages have been extracted from 6 unpublished excavations conducted by the Chester Archaeological Service and its predecessors (Abbey Green, Old Market Hall, Crook Street 1963 and 1973, Foley House, and Goss St. 1968). That in Table 1 can be dated to between the mid 70 s and mid 150s, and that in Table 2 from the mid 70s to $c .120 .{ }^{107}$ In the first assemblage, occupation would have been sparse from $c .120-25$ to $c .160$ because most of the legion would have been away from the fortress on the northern frontier.

Chesterholm, Northumberland was an auxiliary fort on the line of the Stanegate to the rear of Hadrian's Wall. The assemblage used in the analysis discussed above on p. 85 came from the NE corner of the second stone fort and was associated with the occupation of $c .225-275 / 300$. Typologically the material from this site was nearly all late 2 nd-mid 3 rd c., so the unstratified material was included in the quantification. ${ }^{108}$ The

98 Allen ibid. 107 no. 42.

99 R. Wheeler and T. Wheeler, "The Roman amphitheatre at Caerleon, Monmouthshire," Archaeologia 78 (1928) 111-218

100 D. Allen, "The glass," in D. Evans and V. Metcalf, Roman Gates, Caerleon (Oxbow Monograph 15, 1992) 179-85.

101 J. Price, "The Roman glass," in P. Casey and B. Hoffmann, "Excavations at Alstone Cottage, Caerleon, 1970," Britannia 26 (1995) 80-88.

102 J. Price and H. Cool, "The vessel glass," in M. Darling and D. Gurney, Caister-on-Sea. Excavations by Charles Green, 1951-55 (East Anglian Arch Rep. 60, 1993) 141-52.

103 Price (supra n.66) 164-79; H. Cool and J. Price, "The Roman vessel and window glass," within T. Padley, "The metalwork, glass and stone objects from Castle St., Carlisle: excavations 1981-2," in M. McCarthy, Roman waterlogged remains at Castle St. (Cumberland \& Westmorland Ant \& Arch. Soc. Res. Ser. 5, 1991, fasc. 2) 165-76; H. Cool, "The vessel glass," in I. Caruana, "Carlisle: excavation of a section of the annexe ditch of the first Flavian fort, 1990," Britannia 22 (1992) 63-68.

104 The glass has been studied by J. Price and S. Cottam and we are grateful to them and the director of the Carlisle Archaeological Unit for allowing us access to the archive catalogue.

105 H. Cool and J. Price, "The vessels and objects of glass," in Cool and Philo (supra n.43) 141-92.

106 For an interim report on the site, see P. Wilson, "Recent work at Catterick," in P. Wilson, R. Jones and D. Evans (edd.), Settlement and society in the Roman North (Leeds 1984) 75-82.

107 For a general description of the fortress, see P. Carrington, English Heritage book of Chester (London 1994) 24-49.

108 J. Price, "The glass," in P. Bidwell, The Roman fort of Vindolanda at Chesterholm, Northumberland 
EVE values used in the analysis are as follows: drinking vessels 2.6 , bowls 0.8 , jars 0.17 , flask 0.2 , jugs 0.42 , bottles 3.22 .

Claydon Pike, Glos. was a rural site which had developed a temple by the late Roman period. The 4th-c. assemblage in Table 4 comes from the unpublished excavations carried out by the Oxford Archaeological Unit.

Colchester, Essex was a colonia and the glass used here comes from the excavations at Lion Walk, Culver St., and Long Wyre St., which all lie within the walls, and Balkerne Lane which lies immediately outside. Assemblages of 65-150 (for Tables 1 and 2), the 4th-c. (Table 4), and drinking vessels from contexts dated to between $c .65$ and 100 (Table 5) have been extracted from the published data. ${ }^{109}$

Dalton Pariours, W Yorks. was a late Roman villa site where occupation ceased c.370. It contributes a 4th-c. assemblage to Table $4 .{ }^{110}$

Dorchester, Dorset was the capital of the civitas of the Durotriges. The assemblages used are one from contexts dated to c.70-150 (Tables 1 and 2) and a 4th-c. one (Table 4). They are derived from city-centre sites, the largest of which was Greyhound Yard, with small additional amounts derived from the County Hall excavations and the unpublished excavations by the Wessex Archaeological Trust in 1989 at Charles St. ${ }^{111}$

Frocester Court, Glos. was a late Roman villa site which contributes a 4th-c. assemblage to Table $4 .{ }^{112}$

Gloucester, Glos. was the site of a legionary fortress from the late Neronian period. Towards the end of the 1st c. (c.96-98) military control was withdrawn and the site became a civilian colonia. The glass assemblages used are drawn mainly from the unpublished excavations at Berkeley St. and Eastgate St. (directed by H. Hurst), ${ }^{113}$ with additions where appropriate from the excavations at Old Market Hall, at Westgate St., and at the East and North Gates. ${ }^{114}$ The assemblage used in Table 1 comes from contexts dating to between $c .70$ and 150 and is thus a mixed military and civilian assemblage. That in Table 2 is a purely military assemblage of $c .70-98$ derived from barracks, as is the drinking vessel assemblage in Table 5. The 4th-c. assemblage is an intramural civilian one.

Harlow, Essex. The assemblage in Table 2 came from a pit found while excavating the foundations of a garage ${ }^{115}$ It also contained a large quantity of samian and coarse pottery, and animal bones. No other details are known of the immediate circumstances, but Harlow appears to have been a small town during the Roman period, possibly around a cult centre. ${ }^{116}$

Housesteads, Northumberland was an auxiliary fort on Hadrian's Wall. The assemblage in Table 2 was recovered from an Antonine drain deposit in the commandant's house. ${ }^{117}$

Lincoin was initially a legionary fortress and then became a colonia in the late $1 \mathrm{st} c$. The assemblage in Tables 1 and 2 came from unpublished excavations at the Park ${ }^{118}$ and is part of the late 2nd-early 3rd c. rubbish that

(HBMCE Arch. Rep. 1, 1985) 207-13.

109 Colchester.

110 J. Price, "The glass," in S. Wrathmell and A. Nicholson (edd.), Dalton Parlours Iron Age settlement and Roman villa (Yorkshire Archaeology 3, 1990) 99-105.

111 H. Cool and J. Price, "Roman glass," in P. Woodward et al. (supra n.87) 150-67; H. Cool, "Roman glass," in R. Smith, Excavations at County Hall, Colliton Park, Dorchester, Dorset, 1988 in the north-west corner of Durnovaria (Wessex Archaeology Rep. 4, 1993) 39-40.

112 J. Price, "The glass," in H. Gracie and E. Price, "Frocester Court Roman villa. Second report 1968-77: the courtyard," TBGAS 97 (1979) 37-46.

113 For interim reports on these sites see H. Hurst, Ant] 52 (1972) 37-52; id., AntJ 54 (1974) 23.

114 D. Charlesworth, "Glass vessels," in M. Hassall and J. Rhodes, "Excavations at the New Market Hall, Gloucester 1966-7," TBGAS 93 (1974) 75-76; J. Price, "Roman glass from 1, Westgate Street, Gloucester," in C. Heighway and P. Garrod, "Excavations at nos. 1 and 30 Westgate St., Gloucester: the Roman levels," Britannia 11 (1980) 110-14; J. Price, "The Roman vessel glass," in C. Heighway, The East and North Gates of Gloucester (Bristol 1983) 168-70.

115 J. Price, "Glass from Felmongers, Harlow in Essex. A dated deposit of vessel glass found in an Antonine pit," AnnAIHV 10 (1987) 185-206.

116 For Harlow see B. C. Burnham and J. Wacher, The 'small towns' of Roman Britain (London 1990) 183-88.

117 The glass is published in D. Charlesworth, "A group of vessels from the Commandant's house, Housesteads," JGS 13 (1971) 34-37. The site narrative is in D. Charlesworth "The Commandant's house, Housesteads," ArchAel ser. 5, vol. 3 (1975) 17-42.

118 For an interim report on the site see C. Colyer, "Excavations at Lincoln 1970-1972: the western defences 
was incorporated into the rampart behind the wall of the lower town.

London appears to have become the provincial capital sometime after the Boudican rising in $60 / 61$. The assemblage used in Table 2 and Table 5 comes from Leadenhall Court and derives from the series of buildings and their associated middens that were built c.75 and demolished prior to the building of the Forum Basilica on the site in c.95-100. The assemblage in Table 2 comes from the occupation of these buildings (Periods 3 and $4 c .75-90)$, and the drinking vessel assemblage in Table 5 consists of all the relevant material stratified in these phases together with that from Period 2 (the farmsteads that preceded Phase 3, dated to 65-75) and Phase 5 (the civic building site, 95-100). ${ }^{119}$

Pentre Farm, Flint was the site of a building complex thought to be associated with the official exploitation of the lead mines between c.120 and 200. It was demolished in the mid 3rd c. ${ }^{120}$ Given the lack of earlier or later occupation, unstratified material has also been included in the quantification of the assemblage in Table 2.

Portchester, Hants. was a fort built in the late $3 \mathrm{rd} \mathrm{c}$. that formed part of the Saxon shore defensive system. It contributes a 4 th-c. assemblage to Table 4.21

Rocester, Staffs. was the site of an auxiliary fort of the late 1st-early 2 nd c. which was subsequently abandoned. A second auxiliary fort was build in the period 140-60 and demolished c.200. The assemblage in Table 2 comes from the second fort. ${ }^{122}$

Stanwick, Northants. The 4th-c. assemblage in Tables 1 and 4 comes from the Stanwick villa excavated as part of the Raunds area landscape project undertaker by the Central Archaeological Service (unpublished). ${ }^{123}$

Towcester, Northants. was a small defended town. The 4th-c. assemblages in Tables 1 and 4 come from the extramural excavations to the south-west of the town. ${ }^{124}$ The assemblage of $c .155-65$ was found in the filling of a well at the back of a public building inside the town. The deposit also included a large quantity of samian, coarse pottery, and animal bone. ${ }^{15}$

Uley, Glos., a substantial rural cult centre devoted to Mercury, contributes a 4 th-c. assemblage to Table $4 .{ }^{126}$

Verulamium, Herts. was the capital of the civitas of the Catuvellaunorum. The assemblage of $150-60$ is derived from the occupation of a tenement in Insula XIV which was destroyed by fire and then levelled.127 The assemblage has been derived from the published sources. It is possible that the bottles are underrepresented.

Wilcote, Oxon. was a small roadside settlement where occupation started in the pre-Flavian period and continued into the 4th $c$. A small assemblage was extracted from stratified contexts of Flavian to mid 2nd $c$. date ${ }^{128}$ and used in the analysis reported on above (p. 83). The EVE values are as follows: drinking vessels 0.2 , bowls 1.0, jars 0 , flasks 0.07 , jugs 0.49 , bottles 1.0 .

of the lower town." ArchI 55 (1974) 228-45.

119 J. Shepherd, "Glass," in Milne and Wardle (supra n.83) 99-114.

120 J. Price, "The glass," in T. O'Leary, Pentre Farm, Flint, 1976-81. An official building in the Roman lead mining district (BAR Brit. Ser. 207, 1989) 77-86.

121 D. Harden, "The glass," in B. Curliffe, Excavations at Portchester I: Roman (RepSocAnt 32, 1975) 368-75.

$122 \mathrm{H}$. Cool, "The Roman vessel glass," in A. Esmonde Cleary and I. Ferris, Excavations at the New Cemetery, Rocester, Staffordshire, 1985-1987 (Trans. Staffordshire Arch. \& Hist. Soc. 35, 1993-94 [1996]) 106-21.

123 For an interim report see D. Neal, "The Stanwick villa, Northants: an interim report on the excavations of 1984-88," Britannia 20 (1989) 149-68.

124 J. Price and H. Cool, "Glass from the excavations of 1974-76," in A. Brown and C. Woodfield, "Excavations at Towcester, Northamptonshire: the Alchester Road suburb," Northamptonshire Archaeology 118 (1983) 115-24.

125 J. Price, "The Roman glass," in Lambrick (supra n. 44) 63-68.

126 J. Price, "Vessel glass," in A. Woodward and P. Leach, The Uley shrines. Excavation of a ritual complex on West Hill, Uley, Gloucestershire: 1977-9 (English Heritage Arch. Rep. 17, 1993) 210-15.

127 D. Charlesworth, "The glass," in S. S. Frere, Verulamium I (RepSocAnt 28, 1972) 196-215.

128 H. Cool, "The glass and frit," in A. Hands, The Romano-British roadside settlement at Wilcote, Oxfordshire I. Excavations 1990-92 (BAR Brit. Ser. 232, 1993) 158-63; ead., "The glass and frit," in A. Hands, The Romano-British roadside settlement at Wilcote, Oxfordshire II. Excavations 1993-96 (BAR Brit. Ser. 265, 1998) 240-44. 
Winchester, Hants. was the capital of the civitas of the Belgae. The 4th-c. assemblage used in Table 1 is the combined unpublished assemblages of the intramural site at the Brooks ${ }^{129}$ and northern extramural site of Victoria Road excavated by the Winchester City Archaeology Office. In Table 4 these have been divided into intra- and extramural assemblages.

Wroxeter. Shrops. was a legionary base founded in the Neronian period whose site became the capital of the civitas of the Cornovii. It probably passed into civilian control sometime in the 80s. The assemblage of $c .80-$ 150 in Tables 1 and 2 was derived from material stratified in contexts associated with the civilian occupation from the unpublished excavations of G. Webster. The assemblage dated to $c .175-225$ in Table 2 comes from the rubbish pits in the portico of the macellum from the same excavations. The 4 th-c. assemblage in Table 4 comes from the same excavations together with material from the neighbouring excavations of $P$. Barker. The drinking vessel assemblage in Table 5 is derived from contexts associated with the earliest civilian occupation dated to $c .80-120$ and found during Webster's excavations. ${ }^{130}$

York, $N$. Yorks. was one of the three permanent legionary fortresses in Britannia. It was founded on the NW bank of the Ouse in c.71-74, and a civilian settlement grew up on the SE bank in the later 2nd c. By 237 a colonia existed at York, and this is generally equated with the settlement on the SE bank. The 1st-2nd c. assemblage used in Tables 1 and 2 comes from the excavations within the fortress and is mainly derived from 9 Blake Street, with a small amount of additional material from various sites in the Swinegate area. ${ }^{131}$ It may be dated from c.71-77 to $c .160$, though occupation would have been sparse from c.120-25 to $c .160$ because most of the legion would have been on the northern frontier. The second assemblage in Table 2, dated to c.175250, comes from the excavations at the General Accident Extension site, 24-30 Tanner Row, in the civilian settlement. ${ }^{132}$ The third assemblage in Table $2(c .160-280)$ was recovered in the Period 4a contexts of Blake Street within the fortress. The 4th-c. assemblage in Tables 1 and 4 comes from the Blake Street excavations and those at the Minster in the centre of the fortress. ${ }^{133}$ The drinking vessel assemblage in Table 5 is derived from the Phase 2 contexts at Blake Street.

\section{APPENDIX 2: CORRESPONDENCE ANALYSIS AND ROMAN ARCHAEOLOGY}

In a keynote addiress to the 25th Computer Applications in Archaeology conference in 1997, I. Scollar identified CA as one of the great successes of the conference. In the space of 10 years the technique had moved from being little known or used to being regularly applied in papers delivered by archaeologists who have little statistical training. Viewed simply as a technique for converting large tables of numbers to a more easily digested pictorial form, $\mathrm{CA}$ is ideally suited to the presentation and interpretation of certain kinds of archaeological data. Its adoption by the archaeological community has been spasmodic. In 1994 Baxter (supra n.20) surveyed its geographical spread within archaeology. CA was used by French scholars from the mid-1970s and began to be popularised as a result of English-language publications by Scandinavian scholars in the early 1980s. Publications by British scholars began to increase from the late 1980 s but, at the time the survey concluded in the early 1990s, there had been few applications by American archaeologists or in American publications, and this is still largely the case.

129 For an interim report, see G. Scobie, J. Zant and R. Whinney, The Brooks, Winchester. A preliminary report on the excavations, 1987-88 (Winchester Museums Service Arch. Rep. 1, 1991)

130 We are grateful to K. Pretty for granting access to the glass from P. Barker's excavations. For a summary of the civilian occupation at Wroxeter, see J. Wacher, The towns of Roman Britain (2nd ed., London 1995) 362-77.

131 The glass from Blake St. and Swinegate is published in Cool et al. (supra n.89) 1559-88, 1608-11, 165061, 1666-68. The structural narrative for the Blake St. excavations is published in R. Hall, Excavations in the Praetentura: 9 Blake Street (The Archaeology of York 3/4, 1997).

132 The vessel glass from this site is unpublished but a structural narrative of the site is available in J. Perrin, Roman pottery from the colonia 2: General Accident and Rougier Street (The Archaeology of York $16 / 4,1990) 243-45$. The glass comes from contexts of phases 6 and 7.

133 J. Price, "Roman glass," in D. Phillips and B. Heywood, Excavations at York Minster 1. From Roman fortress to Norman cathedral (London 1995) 346-71. 
There is a bias in the areas of archaeology to which CA has been applied. The majority of the references in Baxter (supra n.20) are to applications involving material from prehistoric contexts. There is a smattering of references to post-Roman material but applications to Roman material are almost entirely absent. We shall not speculate here on the reasons for such bias. The mathematics of CA (though not its output) can be difficult to understand, and this may have deterred some users. Until recently the technique has not been widely available in commercially-supported software packages. This situation has changed, and this may promote further use of the method. For those fortunate enough to have access to software of the kind to be found in academic institutions, the latest releases of MINITAB, SPSS and S-PLUS are among packages that support CA. For those less fortunate, I. Scollar's WINBASP package is an affordable, though more specialised, option.

Given that Roman archaeology is a data-rich discipline often producing tables that could usefulty be explored by CA, it seems to us that it is a technique that Romanists should consider using more often. We have therefore collected here recent applications of the technique to Roman data to give an indication of the range of problems that it has been helpful in exploring.

A very common use of $\mathrm{CA}$ is for seriation to explore chronological pattern. It has been used in this way to re-examine the generally-accepted chronology of Republican denarii, ${ }^{134}$ and to explore the chronology of the Rheinzabern potters. ${ }^{135}$ Chronology can obscure non-temporal patterns of interest, as this paper has shown. To study such patterns it is sensible, should the data permit, to focus on more narrowly defined date-ranges than covered by the full data set. Our work in this paper is in this spirit. It has also been explored by $\mathrm{K}$. Lockyear in his work on the republican coin hoards in Dacia. ${ }^{136}$ Other uses of $\mathrm{CA}$ to explore non-chronological variation in Roman finds assemblages have been noted above. ${ }^{137}$ It has also been used to explore the evidence relating to kiln load make-up in the La Gaufesenque samian potteries, ${ }^{138}$ and to explore the spread of literacy in Roman Britain based on the evidence of graffiti on pottery. ${ }^{139}$

134 D. Backendorf and A. Zimmermann, "Bemerkungen zur Seriation römische-republikanischer Münztypen," in J. Muller and A. Zimmermann (edd.), Archäologie und Korrespondenzanalyse: Beispiele, Fragen, Perspectiven (Internationale Archäologie 23; Espelkamp 1997) 175-78.

135 K. Kortüm and A. Mees, "Die Datierung der Rheinzaberner Reliefsigillata," in J. Bird (ed.), Form and fabric (Oxbow Monograph 80, 1998) 157-68.

136 The problem is noted in K. Lockyear, "Dmax based cluster analysis and the supply of coinage to Iron Age Dacia," Analecta Praehistorica Leidensia 28.1 (1996) 165-78, and is addressed extensively in the same author's Multivariate money. A statistical analysis of Roman Republican coin hoards with special reference to material from Romania (PhD., University College London 1996).

137 See Cool et al. (supra n.89); Moreno-Garcia et al. (supra n.91); Orton (supra n.91).

$138 \mathrm{M}$. Polak, "Old wine in new bottles. Reflections on the organisation of the production of terra sigillata at La Graufesenque," in Bird (supra n.135) 115-21.

139 P. Tyers, Romun pottery in Britain (London 1996) 44-45, fig. 27. 